\title{
Changes in microbial communities and associated water and gas geochemistry across a sulfate gradient in coal beds: Powder River Basin, USA
}

\author{
Authors: Hannah D. Schweitzer, Daniel Ritter, \\ Jennifer Mclntosh, Elliott Barnhart, Alfred B. \\ Cunningham, David Vinson, William Orem, and \\ Matthew W. Fields
}

NOTICE: this is the author's version of a work that was accepted for publication in Geochimica et Cosmochimica Acta. Changes resulting from the publishing process, such as peer review, editing, corrections, structural formatting, and other quality control mechanisms may not be reflected in this document. Changes may have been made to this work since it was submitted for publication. A definitive version was subsequently published in Geochimica et Cosmochimica Acta, VOL\# 245, (January 2019), DOI\# 10.1016/j.gca.2018.11.009.

Schweitzer, Hannah D., Daniel Ritter, Jennifer Mclntosh, Elliott Barnhart, Alfred B. Cunningham, David Vinson, William Orem, and Matthew W. Fields, "Changes in microbial communities and associated water and gas geochemistry across redox gradients in coal beds: Powder River Basin, US," Geochimica et Cosmochimica Acta, January 2019, 245: 495-513. doi: 10.1016/ j.gca.2018.11.009 
Title:

Changes in microbial communities and associated water and gas geochemistry across a sulfate gradient in coal beds: Powder River Basin, USA

Authors: $\quad$ Hannah Schweitzer ${ }^{1,2,3}$, Daniel Ritter ${ }^{4}$, Jennifer Mclntosh ${ }^{4}$, Elliott Barnhart ${ }^{5,3}$, Al B. Cunningham ${ }^{2,3}$, David Vinson ${ }^{6}$, William Orem ${ }^{7}$, and Matthew Fields ${ }^{1,2,3, *}$

Affiliations: $\quad{ }^{1}$ Department of Microbiology and Immunology, Montana State University, Bozeman, MT, 59717, USA

${ }^{2}$ Center for Biofilm Engineering, Montana State University, Bozeman, MT, 59717, USA

${ }^{3}$ Energy Research Institute, Montana State University, Bozeman, MT, 59717, USA

${ }^{4}$ Department of Hydrology and Atmospheric Sciences, University of Arizona, Tucson, Arizona 85721, USA

${ }^{5}$ U.S. Geological Survey, Wyoming-Montana Water Science Center, Helena, MT 59601, USA

${ }^{6}$ Department of Geography and Earth Sciences, University of North Carolina, Charlotte, North Carolina 28223, USA

${ }^{7}$ U.S. Geological Survey, Eastern Energy Resources, Reston, VA 20192 USA

Keywords: methane; coal-dependent methanogenesis; sulfate

Declaration of interest: none

*Corresponding author:

Matthew W. Fields

Center for Biofilm Engineering

366 Barnard Hall

Montana State University

Bozeman, MT 59717

matthew.fields@biofilm.montana.edu 
Abstract. Competition between microbial sulfate reduction and methanogenesis drives cycling of fossil carbon and generation of $\mathrm{CH}_{4}$ in sedimentary basins. However, little is understood about the fundamental relationship between subsurface aqueous geochemistry and microbiology that drives these processes. Here we relate elemental and isotopic geochemistry of coal-associated water and gas to the microbial community composition from wells in two different coal beds across $\mathrm{CH}_{4}$ and $\mathrm{SO}_{4}{ }^{2-}$ gradients (Powder River Basin, Montana, USA). Areas with high $\mathrm{CH}_{4}$ concentrations generally have higher alkalinity and $\delta^{13} \mathrm{C}$-DIC values, little to no $\mathrm{SO}_{4}{ }^{2-}$, and greater conversion of coal-biodegradable organics to $\mathrm{CH}_{4}$ (based on $\delta^{13} \mathrm{C}_{-}-\mathrm{CH}_{4}$ and $\delta^{13} \mathrm{C}-\mathrm{CO}_{2}$ values). Wells with $\mathrm{SO}_{4}{ }^{2-}$ concentrations from 2-10 $\mathrm{mM}$ had bacterial populations dominated by several different sulfate-reducing bacteria and archaea that were mostly novel and unclassified. In contrast, in wells with $\mathrm{SO}_{4}{ }^{2-}$ concentrations $<1 \mathrm{mM}$, the sequences were predominated by presumptive syntrophic bacteria as well as archaeal Methanosarcinales and Methanomicrobiales. The presence of sequences indicative of these bacteria in low $\mathrm{SO}_{4}{ }^{2-}$ methanogenic wells may suggest a syntrophic role in coal biodegradation and/or the generation of methanogenic substrates from intermediate organic compounds. Archaeal sequences were observed in all sampled zones, with an enrichment of sequences indicative of methanogens in low $\mathrm{SO}_{4}{ }^{2-}$ zones and unclassified sequences in high $\mathrm{SO}_{4}{ }^{2-}$ zones. However, sequences indicative of Methanomassiliicoccales were enriched in intermediate $\mathrm{SO}_{4}{ }^{2-}$ zones and suggest tolerance to $\mathrm{SO}_{4}{ }^{2-}$ and/or alternative metabolisms in the presence of $\mathrm{SO}_{4}{ }^{2-}$. Moreover, sequences indicative of methylotrophic methanogens were more prevalent in an intermediate $\mathrm{SO}_{4}{ }^{2-}$ and $\mathrm{CH}_{4}$ well and results suggest an important role for methylotrophic methanogens in critical zone transitions. The presented results demonstrate in situ changes in bacterial and archaeal population distributions along $\mathrm{a} \mathrm{SO}_{4}{ }^{2-}$ gradient associated with recalcitrant, organic carbon that is biodegraded and converted to $\mathrm{CO}_{2}$ and/or $\mathrm{CH}_{4}$. 


\section{Introduction}

In organic-rich formations within sedimentary basins, such as coal beds, complex, methanogenic communities drive the cycling of fossil carbon (coal, shale, oil) and generation of natural gas (methane; $\mathrm{CH}_{4}$ ) (Strąpoć et al., 2008). Different coal beds within or between basins contain different amounts of biogenic $\mathrm{CH}_{4}$, and little is known about the relationship between microbial community dynamics, turnover of recalcitrant carbon, aqueous geochemistry and $\mathrm{CH}_{4}$ concentrations. Sulfate-reducing bacteria (SRB) are assumed to out-compete methanogens for substrates (e.g., $\mathrm{H}_{2}$, acetate, formate) in the presence of $\mathrm{SO}_{4}{ }^{2-}$, while in low $\mathrm{SO}_{4}{ }^{2-}$ conditions $(<1 \mathrm{mM})$, methanogenesis is the terminal process for anaerobic mineralization of organic carbon (Muyzer and Stams, 2008). Yet, little is known about methanogenic activity at marginal $\mathrm{SO}_{4}{ }^{2-}$ levels and/or transition zones in terrestrial environments (Ma et al., 2017). In addition, little is known about methanogens that utilize alternative (non-competitive with SRB) substrates, such as methanol or other methyl-donors, to produce $\mathrm{CH}_{4}$ potentially under higher $\mathrm{SO}_{4}{ }^{2-}$ conditions (Vinson et al., 2017).

Recent laboratory and pilot field-scale studies have demonstrated that methanogens and associated microbial communities can be stimulated, by addition of nutrients and trace metals, to generate 'new' $\mathrm{CH}_{4}$ to sustain the lifetime of existing coalbed $\mathrm{CH}_{4}(\mathrm{CBM})$ wells (e.g., Ulrich and Bower, 2008; Jones et al., 2010; Barnhart et al., 2017; Davis et al., 2018). In order for microbially enhanced CBM (MeCoM) to be advanced, it is important to understand microbial community dynamics during the conversion of complex organic substrates to $\mathrm{CH}_{4}$ under different in situ environmental conditions (Ritter et al., 2015; Davis et al., 2018).

Much of the previous research on microbial methanogenesis in coal beds has focused on single types of analyses, such as aqueous geochemistry (i.e., alkalinity and $\mathrm{SO}_{4}{ }^{2-}$ concentrations) or the isotopic signature of produced gases (e.g., $\left.\delta^{13} \mathrm{C}_{-} \mathrm{CO}_{2} ; \delta^{13} \mathrm{C}_{-}-\mathrm{CH}_{4} ; \delta \mathrm{D}-\mathrm{CH}_{4}\right)$ to infer metabolic pathways of methanogenesis (i.e., hydrogenotrophic, acetoclastic and/or methylotrophic) and bacterial sulfate reduction (e.g., Flores et al., 2008; Rice et al., 2008; McIntosh et al., 2010). Separate studies have 
investigated the archaeal and bacterial communities in coal beds (e.g., Green et al., 2008; Klein et al., 2008), while only a few studies have compared microbial communities spatially across basins or between different coal beds (Penner et al, 2010; An et al., 2013; Shelton et al., 2016).

Most studies have identified microbial communities associated with the conversion of organic substrates to $\mathrm{CH}_{4}$ via formation water or core samples from single boreholes (e.g. Strąpoć et al., 2008; Jones et al., 2010; Penner et al., 2010; Ünal et al., 2012). However, research has suggested that microbial community characterization through the analysis of microorganisms in formation waters does not fully capture subsurface microbial processes (Alfreider et al., 1997; Penner et al., 2010). Moreover, intact core samples are difficult and costly to collect aseptically. For this reason, down-well incubations have been used as an alternative for community characterizations (e.g. Alfreider et al., 1997; Griebler et al., 2002; Peacock et al., 2004; Reardon et al., 2004), and the present study utilized a down-well incubation technique with a diffusive microbial sampler (DMS) as previously described (Barnhart et al., 2013).

The current study investigated spatial variability of microbial communities in coals and how this distribution is related to $\mathrm{SO}_{4}{ }^{2-}$ concentrations and other aqueous environmental parameters that can be reflected in water and gas isotopic signatures. The study focused in the Powder River Basin (PRB) in Wyoming and Montana, one of the first large basins to undergo intensive development of microbial CBM. Results from this study highlight unique microbial populations across a terrestrial critical zone transition with respect to subsurface recalcitrant carbon and microbial sulfate reduction and methanogenesis.

\section{Background}

\subsection{Microbial Methanogenesis and Bacterial Sulfate Reduction}

Microbial methanogenesis represents the final major step of the biodegradation of organic carbon, which becomes thermodynamically favorable after alternative electron acceptors (e.g., ferric 
iron and $\mathrm{SO}_{4}{ }^{2-}$ ) have been exhausted (Kuivila et al., 1989). Degradation of organic matter under methanogenic conditions involves microbial consortia that break down complex organic matter into intermediate substrates ( $\mathrm{e}^{-}$and/or carbon) such as acetate, formate, $\mathrm{CO}_{2}$, and $\mathrm{H}_{2}$ (Jones et al., 2010; Orem et al., 2010; Strąpoć et al., 2011). Methanogens then convert these simplified compounds to $\mathrm{CH}_{4}$ and $\mathrm{CO}_{2}$ by two dominant pathways: 1) $\mathrm{CO}_{2}$ reduction (hydrogenotrophic methanogenesis), and 2) acetate fermentation (acetoclastic methanogenesis) (Ferry, 1993). $\mathrm{CH}_{4}$ may also be generated by methylotrophic methanogens which use a range of methylated compounds including methanol and methylamines produced by coal kerogen demethoxylation (Strąpoć et al., 2011). Methanol is a noncompetitive substrate that is not utilized by SRB, opening up the possibility that methanogens may coexist with SRBs in coal beds independent of $\mathrm{SO}_{4}{ }^{2-}$ levels (Barnhart et al., 2013), as has been shown in $\mathrm{SO}_{4}$-rich marine sediments (Whiticar, 1996; Whiticar et al., 1986). Moreover, the conditions leading to the development of sulfate reduction over methanogenesis are of particular interest to researchers investigating the potential of stimulating microbial methanogenesis for MeCoM as well as for improved understanding of methane emissions from coal formations as high $\mathrm{SO}_{4}{ }^{2-}$ concentrations can be observed in CBM reservoirs (Ritter et al., 2015).

Studies utilizing carbon stable isotope $\left(\delta^{13} \mathrm{C}\right)$ and $\delta \mathrm{D}$ values of $\mathrm{CH}_{4}$ and $\delta^{13} \mathrm{C}$ values of $\mathrm{CO}_{2}$ in the PRB have suggested that the dominant metabolic pathway for $\mathrm{CBM}$ generation is $\mathrm{CO}_{2}$ reduction (hydrogenotrophic methanogenesis; Flores et al., 2008), whereas some microbial enrichments have shown a predominance and/or mixture of acetoclastic methanogens (Green et al., 2008; Ulrich and Bower, 2008). It is common to observe a shift in the microbial community towards acetoclastic methanogens in laboratory coal enrichment experiments, as acetoclastic methanogens often grow faster compared to hydrogenotrophic methanogens when stimulated with common amendments (e.g., acetate, algal extracts or yeast extracts; Jones et al., 2010; Barnhart et al., 2013). 
The relative dominance of different methanogenic pathways in subsurface, terrestrial environments depends upon multiple factors, including nutrient and carbon availability, salinity, and temperature (Alperin et al., 1992; Zinder, 1993; Nakagawa et al., 2002; Warren et al., 2004; Megonigal et al., 2005). Limited organic substrates and longer water residence times have been shown to favor $\mathrm{CO}_{2}$ reduction, whereas rapid recharge and large supplies of fresh organic matter have been shown to favor acetate fermentation in anoxic wetland sediments (Nakagawa et al., 2002).. In addition, acetoclastic methanogens may be inhibited by the build-up of toxic organic compounds (Warren et al., 2004; Jones et al., 2010) or high salinity (>1 $\mathrm{M} \mathrm{Cl}^{-}$; Waldron et al., 2007). Salinity or temperature limitations for methanogens or SRB are not expected in the PRB as coal waters are relatively dilute $(<5,000 \mathrm{mg} / \mathrm{L}$ total dissolved solids) and formation temperatures are low $\left(<30^{\circ} \mathrm{C}\right)$ (Bates et al., 2011). Rather, we hypothesize that $\mathrm{SO}_{4}{ }^{2-}$ concentrations, which can be variable in the PRB, are the dominant control on methanogenic pathways, and a systematic characterization of bacterial and archaeal communities in PRB coal beds has not been reported in conjunction with changing hydrogeology and geochemistry.

\subsection{Powder River Basin Geology}

The PRB is a drainage and structural basin located in southeastern Montana and northeastern Wyoming (Figure 1A). The basin is bordered by the Bighorn Mountains to the west, Black Hills to the east, and the Casper Arch, Laramie Mountains, and Hartville Uplift to the south and covers approximately $20,000 \mathrm{~km}^{2}$ and asymmetrical with the axis near the western edge (Flores et al., 2008). The basin was formed during the Laramide Orogeny, which also uplifted the surrounding mountains (Anna, 1986). The main coal-bearing unit is the Tertiary Fort Union Formation (700-1800 m thick), deposited 66-58 Ma (Anna, 1986). The uppermost Fort Union Formation (the Tongue River Member) contains sandstone, siltstone, shale, some carbonates and conglomerates, and regionally-extensive thick (up to $77 \mathrm{~m}$ ) coals referred to as the Wyodak-Anderson coal zone (Flores, 2004). Coals were deposited in 
rivers, floodplains, and wetlands in the basin (Flores and Ethridge 1985; Flores, 1986; Lillegraven, 1993; Flores, 2004). Samples collected as part of this study are from the Wyodak-Anderson coal zone (Canyon (Monarch/Carney) and Anderson coals) (Figure 1B).

The Wyodak-Anderson coal zone is a regional aquifer within the Fort Union Formation (Daddow, 1986; Lowry and Wilson, 1983; Bartos et al., 2002) and has been a major target of CBM production since the 1990s. In general, groundwater along the northwestern margin of the PRB, in the study area, flows from the Big Horn Mountains towards the northeast, in the same direction as the Tongue River (Lobmeyer, 1985). Local recharge occurs through clinker deposits that form ridges and hilltops, and act as hydrologic conduits to adjacent coals due to high permeability (Heffern and Coates, 2004).

\subsection{Aqueous Geochemistry of CBM}

Produced waters from PRB coalbeds are primarily $\mathrm{Na}-\mathrm{HCO}_{3}$ type (Lee, 1981; Van Voast, 2003; Brinck et al., 2008; Rice et al., 2008; Bates et al., 2011). Bicarbonate accumulates in CBM systems as a result of the respiration of $\mathrm{CO}_{2}$ from microbially-mediated redox processes (Lee, 1981; Van Voast, 2003; Brinck et al., 2008). Calcite precipitation and cation exchange on clays lowers $\mathrm{Ca}^{2+}$ concentrations and enriches coal waters in $\mathrm{Na}^{+}$. In areas near the basin margin where methanogenesis is absent, waters can contain significant concentrations of $\mathrm{SO}_{4}{ }^{2-}$, in addition to $\mathrm{Na}^{+}$and $\mathrm{HCO}_{3}{ }^{-}$(Brinck et al., 2008).

Nutrients, such as nitrogen and phosphorus, may be limiting in methanogenic environments (Penner et al., 2010; Bates et al., 2011). Total dissolved nitrogen concentrations in the PRB coal waters ranged from 50 to $1000 \mu \mathrm{M}$, and $\mathrm{PO}_{4}{ }^{3-}$ concentrations ranged from below the detection limit to $5 \mu \mathrm{M}$ (Bates et al., 2011). Dissolved organic carbon (DOC) is also important to methanogenesis because intermediate organic substrates, such as long-chain fatty acids, alkanes, and low-molecular-weight aromatics are utilized by syntrophic communities to produce $\mathrm{CH}_{4}$ (Orem et al., 2010; Strąpoć et al., 
2011). Previous measurements of DOC in PRB coal waters ranged from 0.11 to $0.93 \mathrm{mM}$ (Orem et al., 2014).

\subsection{Isotopic tracers of methanogenesis}

Vinson et al. (2017) showed that the difference between $\delta^{13} \mathrm{C}_{-} \mathrm{CH}_{4}$ and $\delta^{13} \mathrm{C}-\mathrm{CO}_{2}$ is challenging to apply to field-based studies, such as previously done in the PRB (Flores et al., 2008), where methanogenesis competes with non-methanogenic pathways, such as bacterial sulfate reduction. This is problematic because it is routinely used to infer the apparent fractionation factor $(\alpha)$ of acetoclastic, hydrogenotrophic, or methylotrophic methanogenesis in cultures. One central reason for this difficulty is that $\delta^{13} \mathrm{C}-\mathrm{CH}_{4}$ and $\delta^{13} \mathrm{C}-\mathrm{CO}_{2}$ values reflect not only the methanogenic fractionation factor, but also the proportion of metabolized carbon $(f)$ that is routed through methanogenesis. The value of $f$ in a system reflects (1) the oxidation state of low-molecular weight (LMW) intermediates (electron balance between $\mathrm{CH}_{4}$ and $\mathrm{CO}_{2}$ ) and (2) the competition between methanogenesis and non-methanogenic processes (e.g., bacterial sulfate reduction). Therefore, $f$ records the extent to which LMW is consumed by methanogenesis. In this study, we analyzed $\delta^{13} \mathrm{C}^{-} \mathrm{CH}_{4}$ and $\delta^{13} \mathrm{C}-\mathrm{CO}_{2}$ in methanogenic coal bed waters to calculate $f$, which was compared to aqueous environmental conditions and the microbial community composition to determine controls on coal biodegradation and microbial methanogenesis.

\section{Methods}

\subsection{Sample locations and coal zones}

Samplers (DMS) and water samples were collected from 7 monitoring wells operated by the Montana Bureau of Mines and Geology (MBMG) in the PRB (Fig. 1; Table 1). All wells sampled were completed in single coal zones. Four of the monitoring wells (WR-33, WR-48, WR-34 and SH-396) were completed in the Anderson coal zone along Young's Creek in Bighorn County, Montana. These wells were along a linear surface transect $\sim 7 \mathrm{~km}$ long. The other 3 monitoring wells (WR-24, CBM02, and 
HWC) were completed in the Canyon Coal $20-35 \mathrm{~km}$ apart. Two of the Canyon wells are located on the west side of the Tongue River, with one well along Young's Creek and the other northwest of the Tongue River Reservoir along Highway 314. The third Canyon well is located along Hanging Woman Creek on the east side of the Tongue River. Water and dissolved gas samples from Canyon coal wells were collected in 2011 and 2014, whereas water and dissolved gas samples from Anderson coal wells were collected in 2013 and 2014 (Table 2). Microbial samples were collected in 2010, 2011, 2012, and 2013 from the Canyon coal wells, and 2012 and 2015 from the Anderson coal wells (Table 3). Microbial samples were not collected at the same time as water and dissolved gas samples; however, there was minimal temporal variability in chemical parameters (i.e., major ion chemistry, water stable isotopes) between sampling dates.

\subsection{Field Sample Collection}

\subsubsection{Water Sampling}

Water samples were collected with a Grundfos submersible pump after three wellbore volumes were pumped and field parameters stabilized (water temperature, $\mathrm{pH}$, and dissolved oxygen). Temperature was measured using an Oakton temperature probe, $\mathrm{pH}$ was measured using an Oakton $\mathrm{pH}$ 110 meter and an Orion Ross Combination electrode, and dissolved oxygen was measured using a YSI meter. All water samples for chemical and isotopic analysis were filtered using a $0.45-\mu m$ syringe tip nylon filter, except for $\mathrm{DOC}$ and nutrients, and stored on ice in the field and in a refrigerator $4{ }^{\circ} \mathrm{C}$ until analysis. Water samples for DOC were filtered through $0.7-\mu \mathrm{m}$ pre-combusted glass fiber filters and kept in 30-mL pre-combusted amber glass bottles. Water samples for nutrient $\left(\mathrm{NH}_{4}{ }^{+}\right.$and $\left.\mathrm{PO}_{4}{ }^{3-}\right)$ analyses were filtered using syringe tip Whatman Polyethersulfone (PES) $0.2-\mu \mathrm{m}$ filters, and kept in $30 \mathrm{~mL}$ HDPE bottles. 
Samples for major cations were collected in 60-mL HDPE bottles with no headspace, and two drops of concentrated Optima Grade nitric acid was added to lower the $\mathrm{pH}$ to $<2$. Samples for anions were collected in DI-washed 60-mL HDPE bottles with no headspace. Samples for carbon stable isotope $\left(\delta^{13} \mathrm{C}\right)$ values of dissolved inorganic carbon (DIC) were collected in glass serum bottles, preserved with mercury chloride, and capped with no headspace. Samples for $\delta^{34} \mathrm{~S}_{-} \mathrm{SO}_{4}{ }^{2-}$ and $\delta^{18} \mathrm{O}_{-} \mathrm{SO}_{4}{ }^{2-}$ were collected in 1-L HDPE bottles and ten drops of concentrated nitric acid were added for to prevent bacterial sulfate reduction.

\subsubsection{Dissolved Gas Samples}

Dissolved gas samples were collected from the monitoring wells after purging and at the same time as the water samples for chemical and isotopic analysis described above. Samples for gas isotopes and gas composition were collected by filling a 5-gallon bucket with water. Next, a dissolved gas bottle manufactured by Isotech Laboratories, Inc. was submerged and inverted. A hose from the well was then inserted into the bottle, and water and gas were allowed to flow into the bottle for approximately 5 minutes. The hose was removed, and the bottle was capped upside down and stored inverted on ice until it was sent to Isotech Laboratories, Inc. for analysis. In addition, in order to measure dissolved $\mathrm{CH}_{4}$ concentration, an additional bottle was filled in a similar manner, but with the submerged bottle remaining upright instead of inverted.

\subsubsection{Microbial Samples}

Samples for microbial community analysis were collected from monitoring wells in the Canyon and Anderson coal beds using a DMS (Barnhart et al., 2013) and from filtered groundwater samples. The DMS cylinder (12.7 cm long and $6.4 \mathrm{~cm}$ in diameter) was filled with $25 \mathrm{~g}$ of subbituminous coal (2 $\mathrm{mm}-$ $4 \mathrm{~mm}$ particle size) from the coal bed to be sampled. Coal particles were enclosed in a mesh within the 
DMS cylinder. DMS samplers were lowered into monitoring wells and allowed to incubate for 3 months, after which time samplers were removed from wells using aseptic techniques and returned to the laboratory for analysis. Following retrieval of the DMS, groundwater samples for microbial analysis were obtained by pumping the well with a Grundfos submersible pump until three wellbore volumes were pumped and field parameters stabilized prior to microbial sampling (as described for water chemistry). Water was filtered through a $0.45-\mu \mathrm{m}$ syringe filter until the filter plugged and no additional water passed through to obtain the maximum concentration of microorganisms for DNA analysis. The filters were immediately stored on dry ice and taken back to the lab for analysis.

\subsection{Analytical Methods:}

\subsubsection{Water and Dissolved Gas:}

Alkalinity was titrated in the field within 12 hours of sample collection using the Gran-Alkalinity titration method (Gieskes and Rogers, 1973). Major cations were analyzed with a Perkin-Elmer Optima 5100DV Inductively Coupled Plasma-Optical Emission Spectrometer (precision $\pm 2 \%$ ), and major anions were analyzed using a Dionex Ion Chromatograph model 3000 with an AS23 analytical column (precision $\pm 2 \%)$ in the Department of Hydrology and Atmospheric Sciences at the University of Arizona in Tucson, Arizona. Charge balance error was less than $5 \%$ for all measured waters, with the exception of water sampled from well WR-33, where the charge balance error was $13.6 \%$, which persisted even after reanalysis of all major ion components. $\delta^{13} \mathrm{C}-\mathrm{DIC}\left(1-\sigma\right.$ precision $\pm 0.3 \%$ ), $\delta^{34} \mathrm{~S}^{-\mathrm{SO}_{4}}{ }^{2-}$ (1- $\sigma$ precision $\pm 0.15 \%$ ) and $\delta^{18} \mathrm{O}^{-\mathrm{SO}_{4}}{ }^{2-}(1-\sigma$ precision $\pm 0.7 \%$ ) were analyzed at the University of Arizona Environmental Isotope Laboratory. Samples were measured on a ThermoQuest Finnigan Delta Plus XL continuous flow gas ratio mass spectrometer.

DOC was determined using a Shimadzu TOC-VCPH analyzer in the U.S. Geological Survey (USGS) Eastern Energy Resources Program Laboratory in Reston, Virginia. The method detection limit was 100 ppb. $\mathrm{NH}_{4}{ }^{+}$and $\mathrm{PO}_{4}{ }^{3-}$ were determined using standard colorimetric methods on a Seal Analytical AQ2 
Automated Discrete Analyzer also in the USGS Laboratory. The detection limit was $0.05 \mathrm{mg} / \mathrm{L}$ for both $\mathrm{NH}_{4}^{+}$and $\mathrm{PO}_{4}^{3-}$.

Dissolved gas molecular and isotopic composition was measured at Isotech Laboratories, Inc. (Champaign, Illinois). Dissolved gases in mole \% were measured by gas chromatography, and $\mathrm{C}$ and $\mathrm{H}$ isotopes of $\mathrm{CH}_{4}$ and $\mathrm{C}$ isotopes of $\mathrm{CO}_{2}$ were measured by isotope ratio mass spectrometry. Select samples were also analyzed for dissolved $\mathrm{CH}_{4}$ concentrations (reported in mmole/L) by gas chromatography. Correlations between chemical constituents were investigated using Principle Components Analysis (PCAs) (Leps and Smilauer, 2003). When multiple water chemistry analyses were available for wells, average values were used in the PCAs.

\subsubsection{Microbiology}

DNA was extracted from the coal and slurry from the DMS samplers and the groundwater filters using a FastDNA Spin Kit for Soil (MP Biomedical) and purified using One Step PCR Clean Up (Zymo Research). The bacterial and archaeal SSU rRNA genes were amplified using a universal prokaryotic primer as described in Takahashi et al. (2014). A 0.8\% agarose gel in TAE buffer was used to check the PCR products for DNA of the correct size. The purified PCR amplicons were sequenced with an Illumina MiSeq (Illumina, San Diego, CA, USA) following the "16S Metagenomics Sequencing Library Preparation" Illumina protocol for paired end sequencing (support.illumina.com/documents/documentation/). Following PCR clean up, purification, and indexing PCR, DNA concentration was determined using PicoGreen stain (Quant-IT, Invitrogen). DNA concentrations were normalized and pooled with a $12.5 \%$ PhiX control library. Forward and reverse reads were joined using QIIME (Caporaso et al., 2010). The sequences were aligned using SILVA (Quast et al., 2013). The aligned reads were quality filtered, chimeras were removed, and OTUs and phylotypes were classified with an $80 \%$ confidence using RDP database with Mothur version 1.38.1 (Haas et al., 2011, Wang et al., 2007). Mothur 1.38.1 was used to 
calculate species richness using Inverse Simpson Index. Canoco was used to compare the inter-species correlations divided by the standard deviation to generate the principal components analysis (PCAs) (Leps and Smilauer, 2003). The cladograms were created using the Linear Discriminant Analysis Effect Size (LEfSe) analysis following the parameters set by Segata et al. (2011).

The qPCR analysis was performed as previously described in Jones et al. (2010) with the following modifications: parameters were adjusted for the use of high-fidelity Kapa ${ }^{\oplus} \mathrm{HiFi}$ HotStart ReadyMixPCR kit according to manufacturers instructions and synthetic DNA (g-Blocks ${ }^{\circledR}$ ) were used to generate the standard curve for absolute quantification.

\section{Results}

\subsection{Geochemistry}

The CBM monitoring wells were divided into two groups based on $\mathrm{SO}_{4}{ }^{2-}$ concentration: "high $\mathrm{SO}_{4}{ }^{2-}$ wells" with $\mathrm{SO}_{4}{ }^{2-}>2 \mathrm{mM}$ and "low $\mathrm{SO}_{4}{ }^{2-}$ wells" with $\mathrm{SO}_{4}{ }^{2-}<1.4 \mathrm{mM}$ (Table 1 ; Fig. 2), as $\mathrm{SO}_{4}{ }^{2-}$ concentration is known to influence microbial community composition (Muyzer and Stams, 2008). Well HWC contained $<0.01 \mathrm{mM} \mathrm{SO}_{4}{ }^{2-}$, and well SH-396 contained 0.03 to $2.60 \mathrm{mM} \mathrm{SO}_{4}{ }^{2-}\left(1.30 \mathrm{mM}^{2}\right.$ average value) (Table 1). These two wells were classified as "low $\mathrm{SO}_{4}{ }^{2-}$ wells". Groundwater samples from the other five monitoring wells (CBM02, WR-34, WR-48, WR-33, WR-24) contained higher $\mathrm{SO}_{4}{ }^{2-}$ concentrations from 2.78 to $11.50 \mathrm{mM}$ (Table 1), and were classified as "high $\mathrm{SO}_{4}{ }^{2-}$ wells".

The two low $\mathrm{SO}_{4}{ }^{2-}$ wells were the only monitoring well samples with substantial concentrations of dissolved $\mathrm{CH}_{4}$, ranging from 0.75 to $3.74 \mathrm{mM}$ (Table 2; Fig. 2a). The high $\mathrm{SO}_{4}{ }^{2-}$ wells contained low dissolved $\mathrm{CH}_{4}$ concentrations from $4.67 \times 10^{-5}$ to $2.37 \times 10^{-3}$. Well WR-33 had the lowest dissolved $\mathrm{CH}_{4}$ concentration, whereas well WR-24 had the highest $\mathrm{SO}_{4}{ }^{2-}$ concentration and second lowest $\mathrm{CH}_{4}$ concentration. Nearby CBM production wells, reported in Bates et al. (2011), contained 29 to 98 mole \% $\mathrm{CH}_{4}$, and little to no detectable $\mathrm{SO}_{4}{ }^{2-}(<0.1 \mathrm{mM})$. Dissolved $\mathrm{CH}_{4}$ was not measured in produced waters from CBM production wells. Thus, we assumed production wells contained at least $10 \mathrm{mM} \mathrm{CH}_{4}$ in order 
to include the reported values (e.g., Figure 2a) at the top of the y-axix for comparison to the shallower groundwater monitoring wells.

Groundwater from all of the monitoring wells contained low dissolved oxygen (DO $\leq 4 \%$ saturation), had $\mathrm{pH}$ values from 7.0 to 8.5 , and temperatures ranging from 9.7 to $15.5^{\circ} \mathrm{C}$ (Table 1). Major ion concentrations were consistent between monitoring wells with similar $\mathrm{CH}_{4}$ concentrations (Table 1). Sodium concentrations were high in all monitoring well samples (16.02-30.95 mM), except for water from well WR-33 (3.03 mM average). In contrast, $\mathrm{Ca}^{2+}, \mathrm{Mg}^{2+}, \mathrm{K}^{+}$and $\mathrm{Cl}^{-}$concentrations were low $(<1.5$ $\mathrm{mM}$ ) in all water samples, except for WR-33 and WR-24. Calcium in WR-33 water was $3.30 \mathrm{mM}$ (average), and $\mathrm{Mg}^{2+}$ in $\mathrm{WR}-33$ and $\mathrm{WR}-24$ was 7.19 and $1.10 \mathrm{mM}$, on average, respectively.

Alkalinity generally increased with increasing dissolved $\mathrm{CH}_{4}$ concentrations (Fig. $2 \mathrm{~b}$ ), with the highest alkalinity value $(28.97 \mathrm{meq} / \mathrm{kg})$ measured in low $\mathrm{SO}_{4}{ }^{2-}$ monitoring wells and $\mathrm{CBM}$ production wells (Bates et al., 2011), except for WR-34, which contained $4.38 \mathrm{mM} \mathrm{SO}_{4}{ }^{2-}$ (high SO${ }_{4}{ }^{2-}$ well) and 17.82 $\mathrm{meq} / \mathrm{kg}$ alkalinity. Alkalinity values of low $\mathrm{SO}_{4}{ }^{2-}$ wells were within the range of $\mathrm{CBM}$ production wells (Bates et al., 2011) (Fig. 2b). Nitrate concentrations were below the mean detection limit of the ion chromatograph in all monitoring well samples, except WR-33, which contained $0.17 \mathrm{mM} \mathrm{NO}_{3}{ }^{-} \mathrm{NH}_{4}{ }^{+}$ concentrations in groundwater from the monitoring wells ranged from $<0.03$ to $0.46 \mathrm{mM}$ (Table 1), whereas $\mathrm{PO}_{4}{ }^{3-}$ concentrations ranged from below detection $(<0.03 \mu \mathrm{M})$ to $1.41 \mu \mathrm{M}$ (Table 1). DOC concentrations in groundwater from monitoring wells ranged from 0.12 to $0.79 \mathrm{mM}$ (Table 1). Values of DOC, and other constituents plotted in Fig. 2 are from dates where dissolved $\mathrm{CH}_{4}$ was also measured (Table 2). Higher $\mathrm{CH}_{4}$ wells were correlated to higher $\mathrm{PO}_{4}{ }^{3-}$ and $\mathrm{DOC}$ concentrations in the Principal Components Analysis (PCA). However, there was no clear relationship between dissolved $\mathrm{CH}_{4}$ and $\mathrm{NH}_{4}^{+}$ concentrations, although the monitoring well (WR-33) with the lowest $\mathrm{CH}_{4}$ and alkalinity concentrations had no detectable $\mathrm{NH}_{4}{ }^{+}$. Other PCA results, which help to summarize the key geochemical similarities 
and differences between the wells across the $\mathrm{SO}_{4}{ }^{2-}$ gradient, are discussed below in relationship to the microbial results.

$\delta^{13} \mathrm{C}$-DIC values generally increased with increasing alkalinity (Fig. 3a; Table 4), with the highest $\delta^{13} \mathrm{C}$-DIC values observed in groundwater from the CBM production wells, previously reported by Bates et al. (2011), and monitoring well $\mathrm{HWC}$ that had the highest dissolved $\mathrm{CH}_{4}$ and lowest $\mathrm{SO}_{4}{ }^{2-}$ concentration. Well SH-396 had $\delta^{13} \mathrm{C}$-DIC values within the range of the low $\mathrm{SO}_{4}{ }^{2-}$ wells. $\delta^{34} \mathrm{~S}-\mathrm{SO}_{4}{ }^{2-}$ values ranged from $-0.3 \%$ o to $22.0 \%$ in groundwater from the monitoring wells, whereas formation water from CBM production wells had $\delta^{34} \mathrm{~S}_{-} \mathrm{SO}_{4}{ }^{2-}$ values ranging from $-4.4 \%$ o to $101.2 \%$ (Bates et al., 2011) (Fig. 3b; Table 4). Wells SH-396, WR-34 and $\mathrm{CBM02}$ had $\delta^{34}{\mathrm{~S}-\mathrm{SO}_{4}}^{2-}$ values $\geq 19.6 \%$.

Only the two, low $\mathrm{SO}_{4}{ }^{2-}$ monitoring wells (HWC and $\left.\mathrm{SH}-396\right)$ and one of the high $\mathrm{SO}_{4}{ }^{2-}$ wells (CBM02) contained enough $\mathrm{CH}_{4}$ to measure $\delta^{13} \mathrm{C}^{-} \mathrm{CH}_{4}$ (Table 2; Fig. 4). For these samples, $\delta^{13} \mathrm{C}-\mathrm{CO}_{2}$ values generally increased with increasing $\delta^{13} \mathrm{C}_{-} \mathrm{CH}_{4}$ values and were within the same range as nearby CBM production wells (Bates et al., 2011) (Fig. 4). The highest $\mathrm{CH}_{4}$ sample (HWC) had the highest $\delta^{13} \mathrm{C}-\mathrm{CH}_{4}$ and $\delta^{13} \mathrm{C}-\mathrm{CO}_{2}$ values and greatest calculated extent of methanogensis (i.e., $f$ value). The ' $\mathrm{f}$ ' contours in Figure 4 were calculated assuming that the $\delta^{13} \mathrm{C}$ value of biodegradable organics (i.e., LMW) within the coals was $-25 \%$ (Vinson et al., 2017).

\subsection{Microbiology}

Fewer microbial operational taxonomic units (OTUs) were detected in the filtered water samples compared to the respective DMS coal slurry samples incubated down-well (Table 3), and there was a more even distribution for each OTU (as shown by the Inverse Simpson index) for the water samples versus the DMS samples. In addition, fewer archaeal sequences were detected in the filtered groundwater samples compared to the DMS slurry samples (6 unique OTUs versus 21 out of 71 versus 294 total sequences, respectively). Moreover, with greater evenness in the sampled water communities, 
fewer correlations were observed between the sampled archaeal sequences from the groundwater and associated geochemistry. Conversely, the DMSs showed increased total sampled OTUs and decreased evenness (Table 3). Microbial communities in the filtered water samples showed little or no correlation to $\mathrm{SO}_{4}{ }^{2-}$ levels or other geochemical parameters in the LEfSe analysis (Fig. S1.) Thus, differences in methanogenic communities along the $\mathrm{SO}_{4}{ }^{2-}$ gradient would not have been observed with analysis of groundwater only, and the DMS samples are the focus of discussed microbial results. For archaea, unique sequences were not detected in the groundwater, and for bacteria, the following groups were enriched in groundwater across all samples: Comamonadaceae, Desulfuromonadaceae, Acidobacteriae, Ignavibacteriae (data not shown). In addition, there was not a substantial temporal variability of DMS or filtered water microbial results between sampling dates, or between the two different coal types (Anderson versus Canyon coals) based on the PCA results. Bacterial communities in samples collected in 2010 were most closely related to samples collected from the same well in 2012 in the PCA. This is consistent with the relatively long residence time of coal waters in the study area, on the order of $10^{3}$ to $10^{4}$ years (Pearson, 2002; Frost and Brinck, 2005; Randle, 2014; Ritter et al., 2015). Thus, microbial results based on sampling date or coal zone are not discussed further.

Irrespective of coal type or time sampled, the bacterial communities from the low $\mathrm{SO}_{4}{ }^{2-}$ wells grouped in the PCA, while the high $\mathrm{SO}_{4}{ }^{2-}$ wells formed a distinct, larger grouping (Fig. 5). Sulfate and $\mathrm{CH}_{4}$ were inversely proportional (Fig. 5). Higher $\mathrm{CH}_{4}$ wells were also correlated to higher $\mathrm{PO}_{4}{ }^{3-}$ and $\mathrm{DOC}$ levels. The coal slurry samples (DMSs) showed 5 dominant bacterial groups associated with the low $\mathrm{SO}_{4}{ }^{2-}$ wells that included families Geobacteraceae, Veillonellaceae, Parachlamydiaceae, Verrucomicrobiaceae, and Oxalobacteraceae (Fig. 5). The bacterial groups Veillonellaceae, Parachlamydiaceae, and Verrucomicrobiaceae were tightly aligned with the $\mathrm{CH}_{4}$ vector in the PCA for the low $\mathrm{SO}_{4}{ }^{2-}$, high $\mathrm{CH}_{4}$ wells (Fig. 5). In contrast, the high $\mathrm{SO}_{4}{ }^{2-}$ wells displayed a larger distribution in the PCA with two subgroups. One group correlated to low $\mathrm{DOC}$ and $\mathrm{Na}^{+}$with co-occurrence of Desulfobacteraceae. The 
second sub-group appeared to be driven more by $\mathrm{NH}_{4}{ }^{+}$levels and had co-occurrence with Peptococcaceae, Rhodocyclaceae, and Comamonadaceae (Fig. 5). The relative abundance graph for the bacteria showed that Desulfobacterales and Clostridales were the most predominant orders in high $\mathrm{SO}_{4}{ }^{2-}$ wells while Desulfuromonadales and unclassified bacteria were the most dominant orders in low $\mathrm{SO}_{4}{ }^{2-}$ wells (Fig. S2).

In terms of the archaeal populations, the low $\mathrm{SO}_{4}{ }^{2-}$ wells were grouped in the PCA, as were the high $\mathrm{SO}_{4}{ }^{2-}$ wells, with the exception of the low $\mathrm{SO}_{4}{ }^{2-}$, Anderson coal well (SH-396) that tracked more with the high $\mathrm{SO}_{4}{ }^{2-}$ wells compared to the HWC samples (Fig. 6). All the classified archaeal sequences were members of the Euryarchaeota phylum for both high and low $\mathrm{SO}_{4}{ }^{2-}$ wells. Five archaeal groups tightly aligned with the $\mathrm{CH}_{4}$ vector for the low $\mathrm{SO}_{4}{ }^{2-}$ wells, and included the genera Methanolinea, Methanospirillum, Methanolobus, Methanoregula, and Methanosaeta (Fig. 6). In the high $\mathrm{SO}_{4}{ }^{2-}$ wells and SH-396, five archaeal populations were grouped, including genera Methanomassiliicoccus, Methanosphaerula, and Methanobacterium, while one archaeal group, an unclassified archaea, correlated to two high $\mathrm{SO}_{4}{ }^{2-}$ wells (WR-34, WR-48) (Fig. 6). The relative abundance graph for the archaea showed that Methanomassiliicoccales was the most predominant order in high $\mathrm{SO}_{4}{ }^{2-}$ wells while Methanosarcinales was the most dominant order in low $\mathrm{SO}_{4}{ }^{2-}$ wells (Fig. S3).

In order to infer potential for methanogenic and $\mathrm{SO}_{4}{ }^{2-}$ reducing activity in the different wells, qPCR analysis was performed tarketing biomarker genes for $\mathrm{SO}_{4}{ }^{2-}$ reduction ( $\left.d s r \mathrm{~B}\right)$ and methanogenesis (mcrA) (Fig. 7). Both $d s r B$ and mcrA were detected in all the samples, but for the higher sulfate wells WR-24 and WR-28 only dsrB was detected. The qPCR results indicated mcrA abundance was higher in the low $\mathrm{SO}_{4}{ }^{2-}$ wells and low in the high $\mathrm{SO}_{4}{ }^{2-}$ wells while the $d s r \mathrm{~B}$ appeared to be highest in the $\mathrm{CBM} 02$ that had 'interemdiate' levels of sulfate (Fig. 7).

When the SSU rRNA gene sequences for both bacteria and archaea from the DMS coal slurry were used in LEfSe analyses, strong linear discriminant analysis scores for several sequences were 
statistically correlated to high or low $\mathrm{SO}_{4}{ }^{2-}$ wells and allowed for further classification from the phylum level to the genus level. Sequences indicative of the PVC super phylum (Planctomycetes, Verrucomicrobia and Chlamydiae) were identified as being prevalent in the low $\mathrm{SO}_{4}{ }^{2-}$ wells and the sequences from the PVC super phylum were further classified at the genus level as Luteolibacter, Parachlamydia and Planctomyces (Fig. 8). LEfSe analyses indicated the following sequences for the low $\mathrm{SO}_{4}{ }^{2-}$ wells: Anaerospora (Veillonellaceae), Janthinobacterium, Massilia, and Oxalicibacterium (Oxalobacteraceae) (Fig. 8). LEfSe identified other sequences indicative of organisms that were not in the PCA and more prevalent in the low $\mathrm{SO}_{4}{ }^{2-}$ wells such as Desulfuromonas, Acidithiobacillus, Methylomonas, and Methylococcus (Fig. 8).

LEfSe further classified sequences that significantly associated with the high $\mathrm{SO}_{4}{ }^{2-}$ wells such as sequences indicative of Simplicispira (Comamonadaceae), Desulfosalsimonas (Desulfobacteraceae), Desulfosporosinus and Desulfitobacterium (Peptococcaceae) (Fig. 8). The LEfSe analysis showed similar archaeal trends as the PCA with no dominant populations for the high $\mathrm{SO}_{4}{ }^{2-}$ wells and Methanoregula and Methanospirillum dominated in the low $\mathrm{SO}_{4}{ }^{2-}$ wells (Fig. 6 and Fig. 8). When LEfSe analysis was used on the filtered coal water samples for both bacteria and archaea, unique populations associated with high $\mathrm{SO}_{4}{ }^{2-}$ wells were not identified and few bacteria and no archaea were identified from the low $\mathrm{SO}_{4}{ }^{2-}$ wells (Fig. S1).

\section{Discussion}

\section{1. $\mathrm{SO}_{4}{ }^{2-}$ controls on methanogenesis}

Environmental conditions, particularly $\mathrm{SO}_{4}{ }^{2-}$ levels, were a dominant control on the microbial community compositions, and microbial populations did not differ significantly between coal beds or temporally for the same well. $\mathrm{SO}_{4}{ }^{2-}$ is often below detection in methanogenic aquifers, and previous studies in various environments have suggested that $\mathrm{SO}_{4}{ }^{2-}$ concentrations must be $<1 \mathrm{mM}$ for 
methanogenesis to commence (Lovley and Klug, 1983; Phelps et al., 1985; Whiticar et al., 1986; Capone and Kiene, 1988; Hoehler et al., 1998; Löffler and Sanford, 2005; Finke et al., 2007). In estuarine sediments, methanogenesis has been shown to be active across a range of $\mathrm{SO}_{4}{ }^{2-}$ levels (1 to $10 \mathrm{mM}$ ) (Sela-Adler et al., 2017), while $\mathrm{SO}_{4}{ }^{2-}$ levels in the $\mathrm{mM}$ range impacted hexadecane to $\mathrm{CH}_{4}$ conversions in contaminated sediments (Ma et al., 2017). Recent work with a methanogenic consortium from coal showed that both methanogens and SRB could be active at $\mathrm{SO}_{4}{ }^{2-}$ levels up to $1 \mathrm{mM}$ (Glossner et al., 2016). Results from our study demonstrate a demarcation of bacterial and archaeal populations around the 1-2 $\mathrm{mM} \mathrm{SO}_{4}{ }^{2-}$ level, suggesting that $\mathrm{SO}_{4}{ }^{2-}$ in conjunction with available organic carbon may impact co-existence and competition between SRB and methanogens. The results also suggest that slower rates of coal biodegradation may set a lower threshhold for $\mathrm{SO}_{4}{ }^{2-}$ tolerance by different microbial trophic groups than observed in near-surface environments with higher rates of carbon turnover.

\subsection{Microorganisms responsible for coal degradation}

Bacterial species are thought to be primarily responsible for coal biodegradation and the fermentation of soluble organics into substrates that are then utilized by methanogens to generate $\mathrm{CH}_{4}$ (Strąpoć et al., 2011; Ritter et al., 2015). Results in this study showed bacterial diversity in all wells was much greater than archaeal diversity, consistent with previous studies in the PRB (Barnhart et al., 2013; 2016) and other coal basins (Strąpoć et al., 2011). However, bacterial diversity was not significantly different between high and low $\mathrm{SO}_{4}{ }^{2-}$ wells. Since bacteria are vital to several processes that are important for $\mathrm{SO}_{4}{ }^{2-}$ reduction and methanogenesis, diversity of bacterial species is expected to be greater than archaeal diversity in CBM aquifers (Penner et al., 2010; Barnhart et al., 2013), as observed in this study.

In our study, sequences indicative of members from the Peptococcaceae family such as Desulfitobacterium and Desulfosporosinus grouped more with the vectors that represented $\mathrm{NH}_{4}{ }^{+}$and 
DOC (or lower $\mathrm{PO}_{4}^{3-}$ ). Known Desulfitobacterium can use a variety of electron acceptors including nitrate, sulfite and halogenated organic compounds (Villemur et al., 2006). Known Desulfosporosinus are a well-studied SRB genus that can utilize a wide variety of energy sources and have been observed in both low and high $\mathrm{SO}_{4}{ }^{2-}$ environments (Pester et al., 2012). In terms of the cosmopolitan SRB from the DMS samples, sequences indicative of Desulfosporosinus and Desulfosalsimonas species were commonly observed. Desulfuromonas sequences were observed in most samples, and based upon cultivated isolates, the genus is incapable of reducing $\mathrm{SO}_{4}{ }^{2-}$ (Lonergan et al., 1996). In addition, a recent isolate from a CBM well, Desulfuromonas carbonis, was reported to reduce $\mathrm{Fe}^{3+}, \mathrm{Mn}^{4+}$, and $\mathrm{S}^{0}$ (An and Picardal, 2015). Therefore, Desulfuromonas-like populations may be responding to geochemical factors other than $\mathrm{SO}_{4}{ }^{2-}$. In high $\mathrm{SO}_{4}{ }^{2-}$ wells, sequences indicative from the family Desulfobacteraceae, such as Desulfosalsimonas, were observed. Known Desulfobacteraceae are Proteobacteria that can reduce $\mathrm{SO}_{4}{ }^{2-}$, sulfites, and $S^{0}$ and are observed in different environments including psychrophilic and saline environments (Kuever, 2014). The genus Desulfatiferula (in the Desulfobacteraceae) has cultivated isolates shown to be anaerobic alkene degraders (Grossi et al., 2011; Hakil et al., 2013) and suggest the potential role of this genus in carbon turnover in high $\mathrm{SO}_{4}{ }^{2-}$ environments.

Several bacterial sequence groups were correlated with the low $\mathrm{SO}_{4}{ }^{2-}$, high $\mathrm{CH}_{4}$ wells. Both $\mathrm{LEfSe}$ and PCA identified sequences indicative of Oxalobacteraceae, Verrucomicrobiaceae, and Parachlamydiaceae. PCA correlated Oxalobacteraceae with low $\mathrm{SO}_{4}{ }^{2-}$ wells, and LEfSe analysis identified three genera within this family: Janthinobacterium, Massilia, and Oxalicibacterium. The Janthinobacterium genus has commonly been observed in psychrophilic environments but also associated with aromatic contamination (e.g., Mojib et al., 2013; Ren et al., 2016). The Massilia genus has been isolated from a variety of environmental and human samples (Kampfer et al., 2011), and recent work documented the ability of novel isolates to degrade phenanthrene and herbicides (Wang et al., 2016; Lee et al., 2017). Oxalicibacterium are oxalic acid utilizing aerobes (Tamer et al., 2002), and 
sequences indicative of Oxalicibacterium populations were previously observed in oilfield formation water (Pavlova-Kostryukova et al., 2014). Our results suggest Oxalabacteracaea may be important to the turnover of complex carbon in low $\mathrm{SO}_{4}{ }^{2-}$ environments. The LEfSe analysis also correlated Planctomyces sequences with low $\mathrm{SO}_{4}{ }^{2-}$ samples. Planctomyces are common to both fresh- and marine water/sediment environments, and Planctomyces have been observed at high numbers in both the oxic and anoxic layers of peat bogs and in $\mathrm{CH}_{4}$-rich cold seep sediments (Ivanova and Dedysh, 2006; Reed et al., 2006).

The LefSe sequence analysis identified the genera Luteolibacter within the Verrucomicrobiaceae family that was correlated with low $\mathrm{SO}_{4}{ }^{2-}$ wells. Known Luteolibacter are hetertrophs capable of utilizing a wide range of polysaccharides including those from algal biomass (Cardman et al., 2014). Parachlamydiacea sequences were grouped with the low $\mathrm{SO}_{4}{ }^{2-}$ wells, and PCA correlated Parachlamydia with low $\mathrm{SO}_{4}{ }^{2-}$ samples. Known Chlamydia and chlamydia-like organisms are obligate-intracellular bacteria that can be animal pathogens but also infect and reside in ubiquitous protists (e.g., amoeba; Delafont et al., 2013). Recent work has shown that environmental Chlamydiae have better host-free survival compared to human pathogens, such as C. trachomatis (Coulon et al., 2012) and wildlife can be a potential reservoir for chlamydia-like organisms (Regenscheit et al., 2012; Delafont et al., 2013). The observation of chlamydia-like sequences enriched in the low $\mathrm{SO}_{4}{ }^{2-}$ samples may suggest a higher occurrence of protists in these wells, but future work is needed to characterize the distribution of possible eukaryotic populations and the potential importance to the system.

A Veillonellaceae sequence vector aligned with low $\mathrm{SO}_{4}{ }^{2-}$ wells in PCA; however, LEfSe analysis did not correlate this group with low $\mathrm{SO}_{4}{ }^{2-}$ samples with high significance (although the group was identified in the hierarchal clustering of low $\mathrm{SO}_{4}{ }^{2-}$ samples for $\mathrm{HWC}$ ). The exact role of this potential group is unknown; however, a recent study suggested a role for Veillonellaceae species as corrinoidproviding microorganisms from contaminated groundwater (Men et al., 2017). Corrinoids are cyclic 
pyrrole molecules that serve as co-factors for enzymes that typically contain vitamin $\mathrm{B}_{12}$ and cobalt, and these enzymes are important for the acetyl-CoA pathway in both bacteria and methanogens (White et al., 2012).

Many of the sequence groups for both high and low $\mathrm{SO}_{4}{ }^{2-}$ samples were indicative of microorganisms capable of using simplified aromatics and/or recalcitrant carbon in energy limited environments and included Geobacter (Geobacteraceae) and Simplicispira. Geobacter are well-studied organisms with some species known to be associated with the break-down of complex organic matter (e.g., Zhao et al., 2016; Chen et al., 2016). Simplicispira have been commonly observed with activated sludge (Lu et al., 2007).

The LEfSe analysis also identified several bacterial groups not observed in the PCAs and included sequences indicative of Propionivibrio, Anaerospora, and Acidithiobacillus. Propionivibrio strains have been shown to degrade quinic acid (hydroaromatic) (Brune et al., 2002) and may contribute to the turnover of intermediate byproducts of coal degradation. The occurrence of Acidithiobacillus sequences is typically associated with autotrophic growth with oxidation of reduced sulfur (including $\mathrm{S}^{0}$ ) in low $\mathrm{pH}$ environments (Nunez et al., 2016); however, the observation of sequences indicative of this group suggests a broader niche space or the existence of micro-niches up-stream.

\subsection{Methanogenic communities}

The archaeal sequence groups Methanolinea, Methanospirillum, Methanolobus, Methanoregula, and Methanosaeta that aligned with the low $\mathrm{SO}_{4}{ }^{2-}$ wells (Fig. 6) were suggestive of a mixture of methanogenic pathways. Cultivated representatives of Methanolinea, Methanospirillum, and Methanoregula are $\mathrm{CO}_{2}$ reducing (hydrogenotrophic) methanogens (Sakai et al. 2012, Parshina et al. 2014, Yamamoto et al. 2014). Knonw Methanosaeta are acetoclastic methanogens and known Methanolobus are methylotrophic methanogens (Mori et al. 2012, Doerfert et al. 2009). The 
methanogenic community in high $\mathrm{SO}_{4}{ }^{2-}$ wells consisted of Methanomassiliicoccus, Methanosphaerula, and Methanobacterium based upon representative sequences. Known Methanosphaerula and Methanobacterium are hydrogenotrophic methanogens (Cadillo-Quiroz et al. 2009, Luo et al. 2002). Methanosphaerula sequences were only observed in well WR-33 and Methanobacterium sequences were observed in both SH-396 and CBM02.

Interestingly, for archaea, the SSU rRNA gene analysis from the DMS indicated the order Methanomassiliiccocales was present all of the wells regardless of $\mathrm{SO}_{4}{ }^{2-}$ levels. While Methanomassiliicoccales was more prevalent in high $\mathrm{SO}_{4}{ }^{2-}$ wells, especially well $\mathrm{CBM} 02$, the methanogen sequence group was also detected in the low $\mathrm{SO}_{4}{ }^{2-}$ wells (particularly $\mathrm{SH}-396$ ). Known Methanomassiliicoccales belong to the Class Thermoplasmata and classified species are methylotrophic methanogens capable of utilizing methanol to produce $\mathrm{CH}_{4}$ (Borrel et al., 2014). Methanomassiliicoccales are evolutionarily distinct from the other detected methanogens and genetic analysis indicates these methanogens may utilize a wide range of methylated compounds (Borrel et al., 2014). Recently, methoxydotrophic methanogens that can utilize coal-derived methoxylated compounds $\left(\mathrm{R}-\mathrm{OCH}_{3}\right)$ were reported (Mayumi et al., 2016), and the presence of methanogenesis-related genes in archaeal phyla beyond the Euryarchaeota has recently been demonstrated (one of the investigated environments being a coal-seam) (Evans et al., 2015; Vanwonterghem et al., 2016). Therefore, novel (and under studied) methanogens and/or methylotrophic methanogens may be able to co-exist with $\mathrm{SRB}$ at relatively high $\mathrm{SO}_{4}{ }^{2-}$ levels because of their ability to utilize non-competitive substrates.

Sequences indicative of methanotrophs (i.e., bacterial $\mathrm{CH}_{4}$ oxidizers) were observed, particularly in the high $\mathrm{CH}_{4}$ wells, including Methylococcaceae (Methylococcus and Methylomonas), and Verrumicrobiacea (Ogiso et al., 2012, Kleiveland et al, 2012). For the DMS, Methylococcus and Methylomonas were more prevalent in low $\mathrm{SO}_{4}{ }^{2-}\left(\right.$ high $\left.\mathrm{CH}_{4}\right)$ wells. In addition, sequences indicative of 
putative archaeal $\mathrm{CH}_{4}$ oxidizers were not observed, although it is possible that the primer sets used did not detect these organisms and they may be present in the environment.

\subsection{Source of nutrients for microbial communities}

Previous studies have hypothesized that microbial communities in coal beds and shales may acquire nutrients (i.e., nitrogen and phosphorus) from groundwater recharge transporting in nutrients from near-surface environments (Bates et al., 2011; Schlegel et al., 2011). Thus, nutrient concentrations would be expected to be higher near recharge areas, at basin margins, and decrease as they are consumed by in situ microbial communities as water moves downgradient. The dominant $\mathrm{N}$-species in coal waters is $\mathrm{NH}_{4}^{+}$, and $\mathrm{NH}_{4}^{+}$concentrations were similar across all of the wells sampled in this study, except for WR-33, which had no detectable $\mathrm{NH}_{4}^{+}$or $\mathrm{PO}_{4}{ }^{3-}$, and the lowest $\mathrm{CH}_{4}$ and alkalinity concentrations. Well WR-33 is located along a fault and contains relatively young, tritiated water, indicating modern waters and recent recharge (Ritter et al., 2015). Bates et al. (2011) also found lower concentrations of $\mathrm{N}$ species in PRB CBM wells near recharge areas. The correlation between $\mathrm{PO}_{4}{ }^{3-}$ and $\mathrm{CH}_{4}$ in the PCA, and higher $\mathrm{NH}_{4}{ }^{+}$values away from recharge zones, supports the hypothesis that nutrients $(\mathrm{N}$ and $\mathrm{P})$ in coal-associated waters are primarily released from organic matter during coal biodegradation or via water-rock reactions, rather than being transported in with groundwater recharge. Consistent with this, Pashin et al. (2014) observed a correlation between $\mathrm{NH}_{3}-\mathrm{NH}_{4}{ }^{+}$and total dissolved solids in the Black Warrior Basin, a similar microbial CBM area that could be the result of ion exchange between silicate minerals and formation water. There was no clear pattern between DOC concentration and wells with higher $\mathrm{CH}_{4}$ concentrations (Fig. $2 \mathrm{~d}$ ), although DOC and $\mathrm{CH}_{4}$ were somewhat correlated in the PCA (Fig. 5), suggesting a complex relationship between available carbon and the extent of methanogenesis. DOC concentrations in all monitoring and production wells were similar to 
concentrations observed in produced waters from the PRB and other coal basins (Orem et al., 2007; Bates et al., 2011; Orem et al., 2014).

\subsection{Chemical and isotopic signatures of microbial activity}

The observed increase in alkalinity with increasing $\mathrm{CH}_{4}$ concentrations (Fig. $2 \mathrm{~b}$ ) was expected as $\mathrm{CO}_{2}$ is a byproduct of both bacterial $\mathrm{SO}_{4}{ }^{2-}$ reduction and methanogenesis (Lee, 1981; Van Voast, 2003; Brinck et al., 2008), and although hydrogenotrophic methanogenesis consumes $\mathrm{CO}_{2}$, the increase in alkalinity shows that more $\mathrm{CO}_{2}$ is produced by coal biodegradation than is consumed. $\delta^{13} \mathrm{C}$-DIC values generally increased with increasing alkalinity and $\mathrm{CH}_{4}$ concentrations (Fig. 3a), consistent with methanogenesis. The well with the highest $\mathrm{CH}_{4}$ concentration (HWC) appears the most 'methanogenic' in terms of elevated alkalinity and $\delta^{13}$ C-DIC values (Martini et al., 2004). It also has the greatest 'extent of methanogenesis' ( $f$ value), in terms of the proportion of $\mathrm{LMW}$ converted to $\mathrm{CH}_{4}$ (Vinson et al., 2017).

Following traditional methods for interpreting gas isotopes (Whiticar et al., 1986), the $\delta^{13} \mathrm{C}$ values of dissolved $\mathrm{CH}_{4}$ and $\mathrm{CO}_{2}$ from well $\mathrm{HWC}\left(\alpha^{13} \mathrm{C}_{\mathrm{CH} 4-\mathrm{CO} 2}=1.076\right)$ would be interpreted to represent hydrogenotrophic methanogenesis, yet the microbial sequence results show evidence indicative for multiple methanogenic pathways, including hydrogenotrophic, acetoclastic, and methylotrophic methanogenesis. This further supports the conclusion by Vinson et al. (2017) that $\delta^{13} \mathrm{C}$ values of $\mathrm{CO}_{2}$ and $\mathrm{CH}_{4}$ cannot be simply applied to infer methanogenic pathways in subsurface systems where multiple methanogenic and non-methanogenic processes may impact $\alpha^{13} \mathrm{C}_{\mathrm{CH} 4-\mathrm{CO} 2}$. Interestingly, well SH-396, which had a lower $\mathrm{CH}_{4}$ concentration, higher $\mathrm{SO}_{4}{ }^{2-}$ concentration, and lower 'extent of methanogenesis' ( $f$ value) compared to HWC, seemed to group with higher $\mathrm{SO}_{4}{ }^{2-}$ wells in terms of the archaeal population. Both SH-396 and HWC appear to contain acetoclastic methanogens, but HWC (the other low $\mathrm{SO}_{4}{ }^{2-}$ well) contained Methanosaeta which is thought to be better suited for scavenging lower acetate concentrations (Jetten et al., 1992). 
Sulfur isotopes of $\mathrm{SO}_{4}{ }^{2-}$ can provide evidence of bacterial $\mathrm{SO}_{4}{ }^{2-}$ reduction, as bacteria preferentially remove ${ }^{32} \mathrm{~S}$, enriching the residual pool of $\mathrm{SO}_{4}{ }^{2-}$ in ${ }^{34} \mathrm{~S}$ (Clark and Fritz, 1997). Most of the methanogenic samples that were analyzed for $\delta^{34} \mathrm{~S}_{-} \mathrm{SO}_{4}$ had non-detectable $\mathrm{SO}_{4}{ }^{2-}$, although the high $\mathrm{CH}_{4}$, low $\mathrm{SO}_{4}{ }^{2-}$ well $\left(\mathrm{HWC}\right.$ ) had a similar $\delta^{34} \mathrm{~S}-\mathrm{SO}_{4}$ value as several of the high $\mathrm{SO}_{4}{ }^{2-}$ wells. Most of the variability in $\delta^{34} \mathrm{~S}^{-\mathrm{SO}_{4}}$ values occurs in samples containing $\mathrm{SO}_{4}{ }^{2-}$ at or below $5 \mathrm{mM}$ (Fig. 3b). Previous studies suggest that high $\mathrm{SO}_{4}{ }^{2-}$ concentrations in parts of the PRB are the result of terrestrial evaporite (gypsum) dissolution and/or pyrite oxidation (Lee, 1981; Van Voast, 2003; Brinck et al., 2008). For samples with substantial concentrations of $\mathrm{SO}_{4}{ }^{2-}(>5 \mathrm{mM}), \delta^{34} \mathrm{~S}^{-\mathrm{SO}_{4}}$ values ranged from $-0.3 \%$ o to $6.5 \%$ and terrestrial evaporite (gypsum) or pyrite oxidation could be a possible source for the $\mathrm{SO}_{4}{ }^{2-}$ (Clark and Fritz, 1997). Well SH-396, which had low, but variable $\mathrm{SO}_{4}{ }^{2-}$ (0.03 to $\left.2.6 \mathrm{mM}\right)$, two of the high $\mathrm{SO}_{4}{ }^{2-}$ wells (CBM02 and WR-34), and a previous CBM production well sample, have higher $\delta^{34} \mathrm{~S}-\mathrm{SO}_{4}$ values $(\geq 19.6 \%$ ), which likely indicates the influence of bacterial $\mathrm{SO}_{4}{ }^{2-}$ reduction. This further confirms that well $\mathrm{SH}-396$ represents a transition zone between bacterial $\mathrm{SO}_{4}{ }^{2-}$ reduction and the early stages of methanogenesis, where methylotrophic methanogens appear to predominate the sampled communities.

\section{Conclusions}

The natural redox gradient from sulfate reducing to methanogenic of some PRB coal beds creates a model environment to study microbial community interactions and controls of microbial cycling of fossil carbon and $\mathrm{CH}_{4}$ generation in the terrestrial subsurface. In addition, implementation of the downhole sampling device, DMS, enabled better characterization of in situ microbial populations and comparisons between planktonic microbial communities and biofilms on coal surfaces.

$\mathrm{CH}_{4}$ concentrations, alkalinity, $\mathrm{SO}_{4}{ }^{2-}$, and $\mathrm{PO}_{4}{ }^{3-}$ concentrations were closely related for samples collected in this study. Water from wells with relatively high $\mathrm{CH}_{4}$ concentrations $(0.75-3.7 \mathrm{mM})$ had high alkalinity concentrations $\left(>9 \mathrm{meq} / \mathrm{kg}\right.$ ) and high $\delta^{13} \mathrm{C}$-DIC values $\left(>5 \%\right.$ ). Wells with high $\mathrm{SO}_{4}{ }^{2-}$ 
concentrations $(>2 \mathrm{mM}$ ) were predominated by sequences indicative of presumptive SRB (Desulfosporsinus, Desulfosalsimonas) with some enrichment for Peptococcaceae, Rhodocyclaceae, and Comamonadaceae, and the latter populations likely contribute to overall coal degradation coupled to bacterial sulfate reduction. Under low $\mathrm{SO}_{4}{ }^{2-}$ conditions $(<1.4 \mathrm{mM})$ with greater extents of methanogenesis (i.e., increased $\delta^{13} \mathrm{C}_{-} \mathrm{CH}_{4}$ and $\delta^{13} \mathrm{C}-\mathrm{CO}_{2}$ values), bacterial and archaeal populations were more diverse, and sequences were predominated by Oxalobacteraceae, Methanomicrobia, Planctomycetes, Methylococcaceae, and Verrucomicrobiaceae. Archaeal sequences were observed in both $\mathrm{SO}_{4}{ }^{2-}$ zones and were predominated by novel unclassified members in the high $\mathrm{SO}_{4}$ wells and Methanosarcinales and Methanomicrobiales in low $\mathrm{SO}_{4}{ }^{2-}$ wells. Sequences indicative of Methanomassiliicoccales, a methylotrophic methanogen, were present throughout both low and high $\mathrm{SO}_{4}^{2-}$ wells.

Archaeal diversity showed a decline as $\mathrm{SO}_{4}{ }^{2-}$ levels increased with a drastic decrease in OTUs of known methanogens that correlated to lower $\mathrm{CH}_{4}$ levels (and lower abundane of $m c r A$ ). The significance of different carbon cycling pathways involved in the turnover of recalcitrant carbon under various redox conditions is still a topic of debate, and unknown $\mathrm{CH}_{4}$ cycling pathways are still being discovered from a variety of environments. Redox transitions exist along gradients of increasingly recalcitrant carbon in many environments and microbial community dynamics coupled with hydrogeochemistry could help determine redox control on microbial processes at the genotypic/ecological level.

\section{Acknowledgements}

This research was supported by the National Science Foundation (EAR-1322805, McIntosh; EAR1322795, Fields, Cunningham), Carbon Management Canada, and the U.S. Geological Survey. Marisa Earll assisted with sample collection. Tim Corley assisted with sample analyses and student laboratory training. The Montana Bureau of Mines and Geology provided access and field assistance to sample 
their monitoring well network. Disclaimer: Any use of trade, firm, or product name is for descriptive purposes only and does not imply endorsement by the U.S. Government.

\section{References}

Alfreider A., Krössbacher M. and Psenner R. (1997) Groundwater samples do not reflect bacterial densities and activity in subsurface systems. Water Res. 31, 832-840.

Alperin M. J., Blair N. E., Albert D. B., Hoehler T. M. and Martens C. S. (1992) Factors that control the stable carbon isotopic composition of methane produced in an anoxic marine sediment. Global Biogeochemical Cycles 6, 271-291.

An D., Caffrey S. M., Soh J., Agrawal A., Brown D., Budwill K., Dong X., Dunfield P. F., Foght J., Gieg L. M., Hallam S. J., Hanson N. W., He Z., Jack T. R., Klassen J., Konwar K. M., Kuatsjah E., Li C., Larter S., Leopatra V., Nesbø C. L., Oldenburg T., Pagé A. P., Ramos-Padron E., Rochman F. F., Saidi-Mehrabad A., Sensen C. W., Sipahimalani P., Song Y. C., Wilson S., Wolbring G., Wong M.-L. and G. Voordouw (2013) Metagenomics of hydrocarbon resource environments indicates aerobic taxa and genes to be unexpectedly common. Environ. Sci. Technol. 47, 10708-10717.

An T.T. and Picardal F.W. (2015) Desulfuromonas carbonis sp. nov., an Fe(III), S0, and Mn(IV)-reducing bacterium isolated from an active coalbed methane gas well. Inter. J. Syst. Evol. Microbiol. 65, 16861693.

Anna L. O. (1986) Geologic framework of the ground-water system in Jurassic and Cretaceous rocks in the Northern Great Plains in parts of Montana, North Dakota, South Dakota, and Wyoming. USGS Professional Paper, 1402-B.

Barnhart E. P., De León K. B., Ramsay B. D., Cunningham A. B. and Fields M. W. (2013) Investigation of coal-associated bacterial and archaeal populations from a diffusive microbial sampler (DMS). Inter. J. Coal Geol. 115, 64-70.

Barnhart E. P., Weeks E. P., Jones E. J. P., Ritter D. J., Mclntosh J. C., Clark A. C., Ruppert L. F., Cunningham A. B., Vinson D. S., Orem W. and Fields, M. W. (2016) Hydrogeochemistry and coalassociated bacterial populations from a methanogenic coal bed. Inter. J. Coal Geol. 162, 14-26.

Barnhart E.P., Davis K. J., Varonka M., Orem W., Cunningham A. B., Ramsay B. D. and Fields M. W. (2017) Enhanced coal-dependent methanogenesis coupled with algal biofuels: potential water recycle and carbon capture. Inter. J. Coal Geol. 171, 69-75.

Borrel G., Parisot N., Harris H. M., Peyretaillade E., Gaci N., Tottey W., Bardot O., Raymann K., Gribaldo S., Peyret P., O'Toole P. W. and Brugere J. F. (2014) Comparative genomics highlights the unique biology 
of Methanomassiliicoccales, a Thermoplasmatales-related seventh order of methanogenic archaea that encodes pyrrolysine. BMC Genomics 15, 679.

Brune A., Ludwig W. and B. Schink. (2002) Propionivibrio limicola sp nov., a fermentative bacterium specialized in the degradation of hydroaromatic compounds, reclassification of Propionibacter pelophilus as Propionivibrio pelophilus comb. nov and amended description of the genus Propionivibrio. Inter. J. Syst. Evol. Microbiol. 52, 441-444.

Bartos T. T., Ogle K. M., Duncan D. C., Hail Jr W. J., O'Sullivan R. B., Pipiringos G. N., Johnson R. C., Roehler H. W., Hanley J. H. and Honey J. G. (2002) Water quality and environmental isotopic analyses of ground-water samples collected from the Wasatch and Fort Union formations in areas of coalbed methane development: implications to recharge and ground-water flow, eastern Powder River Basin, Wyoming. US Geological Survey Bulletin 2144, 101-115.

Bates B. L., McIntosh J. C., Lohse K. A. and Brooks P. D. (2011) Influence of groundwater flowpaths, residence times and nutrients on the extent of microbial methanogenesis in coal beds: Powder River Basin, USA. Chemical Geol. 284, 45-61.

Brinck E. L., Drever J. I. and Frost C. D. (2008) The geochemical evolution of water coproduced with coalbed natural gas in the Powder River Basin, Wyoming. Environ. Geosci. 15, 153-171.

Cadillo-Quiroz, H., Yavitt, J. B. \& Zinder, S. H. (2009) Methanosphaerula palustris gen. nov., sp. nov., a hydrogenotrophic methanogen isolated from a minerotrophic fen peatland. Inter. J. Syst. Evol. Microbiol. 59, 928-935.

Capone D. G. and Kiene R. P. (1988) Comparison of microbial dynamics in marine and freshwater sediments: Contrasts in anaerobic carbon catabolism1. Limnol. Oceanogr. 33, 725-749.

Caporaso, J. G., Kuczynski, J., Stombaugh, J., Bittinger, K., Bushman, F.D., Costello, E.K., Fierer, N., Pena, A.G., Goodrich, J.K., Gordon, J.I., Huttley, G.A., Kelley, S.T., Knights, D., Koenig, J.E., Ley, R.E., Lozupone, C.A., McDonald, D., Muegge, B.D., Pirrung, M., Reeder, J., Sevinsky, J.R., Turnbaugh, P.J., Walters, W.A., Widmann, J., Yatsunenko, T., Zaneveld, J. and Knight, R. (2010) QIIME allows analysis of high-throughput community sequencing data. Nature Methods. 7, 335-336.

Cardman Z., Arnosti C., Durbin A., Ziervogel K., Cox C., Steen D., and Teske A. (2014).

Verrucomicrobia Are Candidates for Polysaccharide-Degrading Bacterioplankton in an Arctic Fjord of Svalbard. Appl. Environ. Microbiol. 12, 3749-3756.

Chen M.J., Tong H., Liu C. S., Chen D. D., Li F. B. and Qiao J. T. (2016). A humic substance analogue AQDS stimulates Geobacter sp. abundance and enhances pentachlorophenol transformation in a paddy soil. Chemosphere 160, 141-148.

Clark I. D. and Fritz P. (1997) Environmental isotopes in hydrogeology., CRC press.

Coulon C., Eterpi M., Greub G., Collingnon A., McDonnell G. and Thomas V. (2012) Amoebal host range, host-free survival and disinfection susceptibility of environmental Chlamydiae as compared to Chlamydia trachomatis. FEMS Immunol. Med. Microbiol. 64, 364-373. 
Daddow P. B. (1986) Potentiometric-surface map of the Wyodak-Anderson coal bed, Powder River structural basin, Wyoming, 1973-84. USGS Numbered Series 85, 4305.

Davis K.J., Lu S., Barnhart E. P., Parker A. E., Fields M. W., and Gerlach R. (2018) Type and amount of organic amendments affect enhanced biogenic methane production from coal and microbial community structure. Fuel 211, 600-608.

Delafont V., Brouke A., Bouchon D., Moulin L. and Hechard Y. (2013) Microbiome of free-living amoebae isolated from drinking water. Water Res. 47, 6958-6995.

Doerfert S. N., Reichlen M., Iyer P., Wang M. and Ferry J. G. (2009) Methanolobus zinderi sp. nov., a methylotrophic methanogen isolated from a deep subsurface coal seam. Inter. J. Syst. Evol. Microbiol. 59, 1064-1069.

Evans P. N., Parks D. H., Chadwick G. L., Robbins S. J., Orphan V. J., Golding S. D. and Tyson G. W. (2015) Methane metabolism in the archaeal phylum Bathyarchaeota revealed by genome-centric metagenomics. Science 350, 434-438.

Ferry J. G. (1993) Methanogenesis: Ecology, Physiology, Biochemistry \& Genetics. Springer Science \& Business Media.

Finke N., Hoehler T. M. and Jørgensen B. B. (2007) Hydrogen "leakage" during methanogenesis from methanol and methylamine: implications for anaerobic carbon degradation pathways in aquatic sediments. Environ. Microbial. 9, 1060-1071.

Flores R. M. (2004) Coalbed methane in the Powder River Basin, Wyoming and Montana: an assessment of the Tertiary-Upper Cretaceous coalbed methane total petroleum system. USGS Digital Data Series DDS, 69-C.

Flores R. M. (1986) Styles of coal deposition in Tertiary alluvial deposits, Powder River Basin, Montana and Wyoming. Geological Soc. America Special Papers 210, 79-104.

Flores R. M. and Ethridge F. G. (1985) Evolution of intermontane fluvial systems of Tertiary Powder River basin, Montana and Wyoming. Cenozoic Paleogeography of the West Central U.S. 1985, 107-126.

Flores R. M., Rice C. A., Stricker G. D., Warden A. and Ellis M. S. (2008) Methanogenic pathways of coalbed gas in the Powder River Basin, United States: The geologic factor. Inter. J. Coal Geol. 76, 52-75.

Frost C. D. and Brinck E. (2005) Strontium isotopic tracing of the effects of coal bed natural gas (CBNG) development on shallow and deep groundwater systems in the Powder River Basin, Wyoming. Western Resources Project final report-Produced groundwater associated with coalbed natural gas production in the Powder River Basin: Wyoming State Geological Survey Report of Investigations 55, 93-107.

Gieskes J. M. and Rogers W. C. (1973) Alkalinity determination in interstitial waters of marine sediments. J. Sedimentary Res. 43, 272-277. 
Glossner A.W., Gallagher L. K., Landkamer L., Figueroa L., Munakata-Marr J. and Mandernack K.W. (2016) Factors controlling the co-occurrence of microbial sulfate reduction and methanogenesis in coal bed reservoirs. Inter. J. Coal Geol. 165,121-132.

Green M. S., Flanegan K. C. and Gilcrease P. C. (2008) Characterization of a methanogenic consortium enriched from a coalbed methane well in the Powder River Basin, U.S.A. Inter, J. Coal Geol. 76, 34-45.

Griebler C., Mindl B., Slezak D. and Geiger-Kaiser M. (2002) Distribution patterns of attached and suspended bacteria in pristine and contaminated shallow aquifers studied with an in situ sediment exposure microcosm. Aquatic Microbial Ecol. 28, 117-129.

Grossi V., Cravo-Laureau C., Rontani J. F., Cros M. and Hirschler-Réa A. (2011) Anaerobic oxidation of nalkenes by sulphate-reducing bacteria from the genus Desulfatiferula: $\mathrm{n}$-Ketones as potential metabolites. Res. Microbiol. 162, 915-922.

Haas B. J., Gevers D., Earl A. M., Feldgarden M., Ward D. V., Giannoukos G., Ciulla D., Tabbaa D., Highlander S. K. and Sodergren E. (2011) Chimeric 16 S rRNA sequence formation and detection in Sanger and 454-pyrosequenced PCR amplicons. Genome Res. 21, 494-504.

Hakil F., Amin-Ali O., Hirschler-Rea A., Mollex D., Grossi V., Duran R., Matheron R. and Cravo-Laureau C. (2013) Desulfatiferula berrensis sp. nov., a n-alkene-degrading sulfate-reducing bacterium isolated from estuarine sediments. Inter. J. Syst. Evol. Microbiol. 64, 540-544.

Heffern E. L. and Coates D. A. (2004) Geologic history of natural coal-bed fires, Powder River basin, USA. Inter. J. Coal Geol. 59, 25-47.

Hoehler T. M., Alperin M. J., Albert D. B. and Martens C. S. (1998) Thermodynamic control on hydrogen concentrations in anoxic sediments. Geochimica et Cosmochimica Acta 62, 1745-1756.

Ivanova A. O. and Dedysh S. N. (2006) High abundance of planctomycetes in anoxic layers of a Sphagnum peat bog. Microbiol. 75, 716-719.

Jetten M. S. M., Stams A. J. M. and Zehnder A. J. B. (1992) Methanogenesis from acetate: a comparison oft he acetate metabolism in Methanothrix soehngenii and Methanosarcina spp. FEMS Microbiol. Letts. 88, 181-198.

Jones E. J. P., Voytek M. A., Corum M. D. and Orem W. H. (2010) Stimulation of methane generation from nonproductive coal by addition of nutrients or a microbial Consortium. Appl. Environ. Microbiol. 76, 7013-7022.

Kampfer P., Lodders N., Martin K. and Falsen E. (2011) Revision of the genus Massilia La Scola et al. 2000 , with an emended description of the genus and inclusion of all species of the genus Naxibacter as new combinations, and proposal of Massilia consociate sp. nov. Inter. J. Syst. Evol. Microbiol. 61,15281533.

Klein D. A., Flores R. M., Venot C., Gabbert K., Schmidt R., Stricker G. D., Pruden A. and Mandernack K. (2008) Molecular sequences derived from Paleocene Fort Union Formation coals vs. associated produced waters: Implications for CBM regeneration. Intern. J. Coal Geol. 76, 3-13. 
Kleiveland C.R., Hult L.T.O., Kuczkowska K., Jacobsen M., Lea T., and Pope P.B. (2012). Draft Genome Sequence of the Methane-Oxidizing Bacterium Methylococcus capsulatus (Texas). J. of

Bacteriology 194, 6626-6626.

Kuever J. (2014) The Family Desulfobacteraceae, In E. Rosenberg et al. (eds.), The Prokaryotes $\delta$-Proteobacteria and $\varepsilon$-Proteobacteria, pp. 45-73; Spring-Verlag, Berlin.

Kuivila K. M., Murray J. W., Devol A. H. and Novelli P. C. (1989) Methane production, sulfate reduction and competition for substrates in the sediments of Lake Washington. Geochimica et Cosmochimica Acta 53, 409-416.

Lee R. W. (1981) Geochemistry of water in the Fort Union Formation of the northern Powder River Basin, southeastern Montana. USGS Numbered Series 80, 336.

Lee H., Kim D. U., Park S., Yoon J. H., and Ka J. O. (2017) Massilia chloroacetimicivorans sp. nov., a chloroacetamine herbicide-degrading bacterium isolated from soil. Ant. V Leeuwenhoek 110, 751-758.

Leps J. and Smilauer P. (2003) Multivariate Analysis of Ecological Data using CANOCO. Cambridge University Press.

Lillegraven J. A. (1993) Correlation of Paleogene strata across Wyoming-A user's guide. Geology of Wyoming: Geological Survey of Wyoming Memoir 5, 414-477.

Lobmeyer D. H. (1985) Freshwater heads and ground-water temperatures in aquifers of the Northern Great Plains in parts of Montana, North Dakota, South Dakota, and Wyoming. USGS Numbered Series 1402, D.

Löffler F. E. and Sanford R. A. (2005) Analysis of trace hydrogen metabolism. Meth. Enzymol. 397, 222237.

37.

Lonergran D. J., Jenter H. L., Coates J. D., Phillips E. J. P., Schmidt T. M. and Lovely D. R. (1996). Phylogenetic analysis of dissimilatory Fe(III)-reducing bacteria. J. Bacteriol. 178, 2402-2408.

Lovley D. R. and Klug M. J. (1983) Sulfate reducers can outcompete methanogens at freshwater sulfate concentrations. Appl. Environ. Microbiol. 45, 187-192.

Lowry M. E. and Wilson Jr J. F. (1983) Hydrology of area 50, northern Great Plains and Rocky Mountain coal provinces, Wyoming and Montana. USGS Numbered Series, 83-545.

Luo H.-W., Zhang H., Suzuki T., Hattori S. and Kamagata Y. (2002) Differential expression of methanogenesis genes of Methanothermobacter thermoautotrophicus (formerly Methanobacterium thermoautotrophicum) in pure culture and in cocultures with fatty acid-oxidizing syntrophs. Appl. Environ. Microbiol. 68, 1173-1179.

Lu S.P., Ryu S. H., Chung B. S., Chung Y. R., Park W., and Jeon C. O. (2007) Simplicispora limi sp. nov., isolated from activated sludge. Inter. J. Syst. Evol. Microbiol. 57, 31-34. 
Ma T.-T., Liu L. Y., Rui J. P., Yuan Q., Feng D. S., Zhou Z., Dai L. R., Zeng W. Q., Zhang H. and Cheng L. (2017) Coexistence and competition of sulfate-reducing and methanogenic populations in an anaerobic hexadecane-degrading culture. Biotech. Biofuels 10, 207.

Martini A. M., Nüsslein K., Petsch S. T. and Siegfried R. W. (2004) Enhancing microbial gas from unconventional reservoirs: geochemical and microbiological characterization of methane-rich fractured black shales. Gas Technology Institute-RPSEA GRI-05/0023.

Mayumi D., Mochimaru H., Tamaki H., Yamamoto K., Yoshioka H., Suzuki Y., Kamagata Y. and Sakata S. (2016) Methane production from coal by a single methanogen. Science 354, 222-225.

McIntosh J. C., Warwick P. D., Martini A. M. and Osborn S. G. (2010) Coupled hydrology and biogeochemistry of Paleocene-Eocene coal beds, northern Gulf of Mexico. Geological Soc. America Bulletin 122, 1248-1264.

Megonigal J. P., Mines M. E. and Visscher P. T. (2005) Linkages to trace gases and aerobic processes. Biogeochemistry 8, 317.

Men Y.J., Yu K., Baelum J., Gao Y., Tremblay J., Prestat E., Stenuit B., Tringe S. G., Jansson J., Zhang T. and Alavarez-Cohen L. (2017) Metagenomic and metatranscriptomic analyses reveal the structure and dynamics of a dechlorinating community containing Dehalococcoides mccartyi and corrinoid-providing microorganisms under cobalamin-limited conditions. Appl. Environ Microbiol. 83, 8-14.

Mojib N., Farhoomand A., Andersen D. T. and Bej A. K. (2013) UV and cold tolerance of a pigmentproducing Antarctic Janthinobacterium sp. Ant5-2. Extremophiles 17, 367-378.

Mori K., lino T., Suzuki K.-I., Yamaguchi K. and Kamagata, Y. (2012) Aceticlastic and NaCl-requiring methanogen 'Methanosaeta pelagica' sp. nov., isolated from marine tidal flat sediment. Appl. Environ. Microbiol. 78, 3416-3423.

Muyzer G. and Stams A. J. M. (2008) The ecology and biotechnology of sulfate-reducing bacteria. Nat. Rev. Microbiol. 6, 441-454.

Nakagawa F., Yoshida N., Nojiri Y. and Makarov V. (2002) Production of methane from alasses in eastern Siberia: Implications from its $14 \mathrm{C}$ and stable isotopic compositions. Global Biogeochemical Cycles 16, 14/1-14/15.

Nunez H., Covarrubias P. C., Moya-Beltran A., Issotta F., Atavales J., Acuna L. G., Johnson D. B. and R. Quatrini R. (2016) Detection, identification, and typing of Acidithiobacillus species and strains: a review. Res. Microbiol. 167, 555-567.

Ogiso T., Ueno C., Dianou D., Huy T.V., Katayama A., Kimura M., and Asakawa S. (2012) Methylomonas koyamae sp. nov., a type I methane-oxidizing bacterium from floodwater of a rice paddy field. Inter. J. of Syst. Evol. Microbiology. 62, 1832-1837. 
Orem W. H., Tatu C. A., Lerch H. E., Rice C. A., Bartos T. T., Bates A. L., Tewalt S. and Corum M. D. (2007) Organic compounds in produced waters from coalbed natural gas wells in the Powder River Basin, Wyoming, USA. Appl. Geochemistry 22, 2240-2256.

Orem W. H., Voytek M. A., Jones E. J., Lerch H. E., Bates A. L., Corum M. D., Warwick P. D. and Clark A. C. (2010) Organic intermediates in the anaerobic biodegradation of coal to methane under laboratory conditions. Organic Geochemistry 41, 997-1000.

Orem W., Tatu C., Varonka M., Lerch H., Bates A., Engle M., Crosby L. and McIntosh J. (2014) Organic substances in produced and formation water from unconventional natural gas extraction in coal and shale. Inter. J. Coal Geol. 126, 20-31.

Parshina S. N., Ermakova A. V., Bomberg M. and Detkova, E. N. (2014) Methanospirillum stamsii sp. nov., a psychrotolerant, hydrogenotrophic, methanogenic archaeon isolated from an anaerobic expanded granular sludge bed bioreactor operated at low temperature. Inter. J. Syst. Evol. Microbiol. 64, 180-186.

Pashin J. C., McIntyre-Redden M. R., Mann S. D., Kopaska-Merkel D. C., Varonka M. and Orem W. (2014) Relationships between water and gas chemistry in mature coalbed methane reservoirs of the Black Warrior Basin. Intern. J. Coal Geol. 126, 92-105.

Pavlova-Kostryukova N.K., Tourova T. P., Poltaraus A. B., Feng Q. and T.N. Nazina. (2014) Microbial diversity in formation water and enrichment cultures from the Gangxi bed of the Dagang terrigenous oilfield (PRC). Microbiol. 83:616-633.

Peacock A. D., Chang Y.-J., Istok J. D., Krumholz L., Geyer R., Kinsall B., Watson D., Sublette K. L. and White D. C. (2004) Utilization of microbial biofilms as monitors of bioremediation. Microbial Ecol. 47, 284-292.

Pearson B. N. (2002) Sr isotope ratio as a monitor of recharge and aquifer communication, Paleocene Fort Union Formation and Eocene Wasatch Formation, Powder River Basin, Wyoming and Montana. University of Wyoming Master's Thesis.

Penner T. J., Foght J. M. and Budwill K. (2010) Microbial diversity of western Canadian subsurface coal beds and methanogenic coal enrichment cultures. Intern. J. Coal Geol. 82, 81-93.

Pester M., Brambilla E., Alazard D., Rattei T., Winmaier T., Han J., Lucas S., Lapidus A., Cheng J. F., Goodwin L., Pitluck S., Peters L., Ovchinnickova G., Teshima H., Detter J. C., Han C. S.,Tapia R., Land M. L., Hauser L., Kyrpides N., Ivanova N. N. Pagani I., Huntmann M., Wei C. L., Davenport K. W., Daligault H., Chain P. S. G., Chen A., Mavromatis K., Markowitz V., Szeto E., Mikhailova N., Pati A., Wagner M., Woyke T., Olliver B., Klenk H. P., Spring S. and Loy A. (2012). Complete genome sequences of Desulfosporosinus orientis DSM765, D. youngiae DSM17734, D. meridiei DSM13257, and D. acidophilus DSM22704. J. Bacteriol. 194, 6300-6301.

Phelps T. J., Conrad R. and Zeikus J. G. (1985) Sulfate-dependent interspecies H2 transfer between Methanosarcina barkeri and Desulfovibrio vulgaris during coculture metabolism of acetate or methanol. Appl. Environ. Microbiol. 50, 589-594. 
Quast C., Pruesse E., Yilmaz P., Gerken J., Schweer T., Yarza P., Peplies J., and Glockner F. O. (2013) The SILVA ribosomal RNA gene database project: improved data processing and web-based tools. Nucleic Acid Res. 41, 590-596.

Randle N. L. (2014) Simulating Groundwater Flow Through Methanogenic Coal Beds of the Tongue River Watershed. University of Arizona Master's Thesis.

Reardon C. L., Cummings D. E., Petzke L. M., Kinsall B. L., Watson D. B., Peyton B. M. and Geesey G. G. (2004) Composition and diversity of microbial communities recovered from surrogate minerals incubated in an acidic uranium-contaminated aquifer. Appl. Environ. Microbiol. 70, 6037-6046.

Reed A. J., Lutz, R. A. and Vetriani C. (2006) Vertical adistribution and diversity of bacteria and archaea in sulfide and methane-rich cold seep sediments located at the base of the Florida escarpment. Extremophiles 10, 199-211.

Regenscheit N., Holzwarth N., Greub G., Aeby S., Pospischil A. and Borel N. (2012) Deer as a potential wildlife reservoir of Parachlamydia species. Vet. J. 193, 589-592.

Ren, Y.H., J.J. Niu, W.K. Huang, D.L. Peng, Y.H. Xiao, X. Zhang, Y.L. Liang, X.D. Liu, and H.Q. Yin. (2016) Comparison of microbial taxonomic and functional shift pattern along contamination gradient. BMC Microbiol. 16, 110.

Rice C. A., Flores R. M., Stricker G. D. and Ellis M. S. (2008) Chemical and stable isotopic evidence for water/rock interaction and biogenic origin of coalbed methane, Fort Union Formation, Powder River Basin, Wyoming and Montana U.S.A. Inter. J. Coal Geol. 76, 76-85.

Ritter D., Vinson D., Barnhart E., Akob D. M., Fields M. W., Cunningham A. B., Orem W. and Mclntosh J. C. (2015) Enhanced microbial coalbed methane generation: A review of research, commercial activity, and remaining challenges. Intern. J.Coal Geol. 146, 28-41.

Sakai S., Ehara M., Tseng I.-C., Yamaguchi T., Brauer S. L. Cadillo-Quiroz H., Zinder S. H. and Imachi H. (2012) Methanolinea mesophila sp. nov., a hydrogenotrophic methanogen isolated from rice field soil, and proposal of the archaeal family Methanoregulaceae fam. nov. within the order Methanomicrobiales. Inter. J. Syst. Evol. Microbiol. 62, 1389-1395.

Schlegel M. E., McIntosh J. C., Bates B. L., Kirk M. F. and Martini A. M. (2011) Comparison of fluid geochemistry and microbiology of multiple organic-rich reservoirs in the Illinois Basin, USA: Evidence for controls on methanogenesis and microbial transport. Geochimica et Cosmochimica Acta 75, 1903-1919.

Segata N., Izard J., Waldron L., Gevers D., Miropolsky L., Garrett W. S. Huttenhower C. (2011) Metagenomic biomarker discovery and explanation. Genome Biol. 12, R60.

Sela-Adler M., Ronen Z., Huret B., Antler G., Vigderovich H., Eckert W. and Sivan O. (2017) Co-existence of methanogenesis and sulfate reduction with common substrates in sulfate-rich estuarine sediments. Front. Microbiol. 8, 766. 
Shelton, J.L., Akob, D.M., McIntosh, J.C., Fierer, N., Spear, J.R., Warwick, P.D., and McCray, J.E. (2016) Environmental drivers of differences in microbial community structure in crude oil reservoirs across a methanogenic gradient. Front. Microbiol. 7, 1535.

Strąpoć D., Mastalerz M., Dawson K., Macalady J., Callaghan A. V., Wawrik B., Turich C. and Ashby M. (2011) Biogeochemistry of Microbial Coal-Bed Methane. Ann. Rev. Earth Planetary Sci. 39, 617-656.

Strąpoć D., Picardal F. W., Turich C., Schaperdoth I., Macalady J. L., Lipp J. S., Lin Y.-S., Ertefai T. F., Schubotz F., Hinrichs K.-U., Mastalerz M. and Schimmelmann A. (2008) Methane-producing microbial community in a coal bed of the Illinois basin. Appl. Environ. Microbiol. 74, 2424-2432.

Takahashi S., Tomita J., Nishioka K., Hisada T. and Nishijima M. (2014) Development of a prokaryotic universal primer for simultaneous analysis of Bacteria and Archaea using next-generation sequencing. PLoS One 9, e105592.

Tamer A.U., Aragno M., and Sahin N. (2002) Isolation and characterization of a new type of aerobic, oxalic acid utilizing bacteria, and proposal of Oxalicibacterium flavum gen. nov., sp. nov. Syst. Appl. Microbiol. 25, 513-519.

Ulrich G. and Bower S. (2008) Active methanogenesis and acetate utilization in Powder River Basin coals, United States. Inter. J.Coal Geol. 76, 25-33.

Ünal B., Perry V. R., Sheth M., Gomez-Alvarez V., Chin K.-J. and Nüsslein K. (2012) Trace elements affect methanogenic activity and diversity in enrichments from subsurface coal bed produced water. Frontiers Microbiol. 3, 175.

Van Voast W. A. (2003) Geochemical signature of formation waters associated with coalbed methane. AAPG Bulletin 87, 667-676.

Vanwonterghem I., Evans P. N., Parks D. H., Jensen P. D., Woodcroft B. J., Hugenholtz, P. and Tyson G. W. (2016) Methylotrophic methanogenesis discovered in the archaeal phylum Verstraetearchaeota. Nature Microbiol. 1, 16170.

Villemur R., Lanthier M., Beaudet R., and Lepine F. (2006) The Desulfitobacterium genus. FEMS Microbiol. Rev.5, 706-733.

Vinson, D.S., Blair, N., Martini, A., Larter, S., Orem, B., and McIntosh, J. (2017) Microbial methane from in situ biodegradation of coal and shale: A reevaluation of hydrogen and carbon isotope signatures.

Chem. Geol., 453, 128-145.

Waldron P. J., Petsch S. T., Martini A. M. and Nüsslein K. (2007) Salinity constraints on subsurface archaeal diversity and methanogenesis in sedimentary rock rich in organic matter. Appl. Environ. Microbial. 73, 4171-4179.

Wang H.Z., Lou J., Gu H. P., Luo X. Y., Yang L. , Wu L. S., Liu Y., Wu J. J., and Xu J. M. (2016) Efficient biodegradation of phenanthrene by a novel strain Massilia sp. WF1 isoalted from a PAH-contaminated soil. Environ. Sci. Pollution Res. 23, 13378-13388. 
Wang Q., Garrity G. M., Tiedje J. M., and Cole J. (2007) Naïve Bayesian Classifier for Rapid Assignment of rRNA Sequences into the New Bacterial Taxonomy. Appl Environ Microbiol. 73, 5261-5267.

Warren E., Bekins B., Godsy E. and Smith V. (2004) Inhibition of acetoclastic methanogenesis in crude oil-and creosote-contaminated groundwater. Bioremediation J.8, 1-11.

Whiticar M. J. (1996) Stable isotope geochemistry of coals, humic kerogens and related natural gases. Inter. J. Coal Geol. 32, 191-215.

Whiticar M. J., Faber E. and Schoell M. (1986) Biogenic methane formation in marine and freshwater environments: $\mathrm{CO}_{2}$ reduction vs. acetate fermentation-Isotope evidence. Geochimica et Cosmochimica Acta 50, 693-709.

White D., Drummond J., and Fuqua C. (2012) $C_{1}$ metabolism, In The physiology and biochemistry of prokaryotes, Oxford University Press.

Yamamoto K., Tamaki H., Cadillo-Quiroz H., Imachi H., Kyrpides N., Woyke T., Goodwin L., Zinder S., H., Kamagata Y. and Liu W.-T. (2014) Complete genome sequence of Methanoregula formicica SMSPT, a mesophilic hydrogenotrophic methanogen Isolated from a methanogenic upflow anaerobic sludge blanket reactor. Genome Announ. 2, 5e00870-14.

Zinder S. H. (1993) Physiological ecology of methanogens. In Methanogenesis Springer. pp. 128-206.

Zhao Z.Q., Zhang Y. B., Ma W. C., Sun J. Q., Sun S. L. and Quan Z. (2016) Enriching functional microbes with electrode to accelerate the decomposition of complex substrates during anaerobic digestion of municipal sludge. Biochem. Eng. J. 111, 1-9. 


\section{Figure and Table Legends}

Figure 1. Map showing location of monitoring wells sampled in the Anderson and Canyon coal seams in the Powder River Basin, near the border of Wyoming and Montana, as part of this study. A) Location of monitoring wells in the Anderson( $\mathbf{\square})$ and Canyon $(\bullet)$ coal beds. B) Schematic diagram highlighting depth of Anderson and Canyon coal bed wells and land surface elevation. Monitoring wells are divided into two groups based on $\mathrm{SO}_{4}{ }^{2-}$ concentrations: (1) "High $\mathrm{SO}_{4}$ wells" with $\left[\mathrm{SO}_{4}{ }^{2-}\right]>2 \mathrm{mM}$ (red), and (2) "Low $\mathrm{SO}_{4}$ wells" with $\left[\mathrm{SO}_{4}{ }^{2-}\right]<1.4 \mathrm{mM}$ (green).

Figure 2. Dissolved $\mathrm{CH}_{4}$ in selected groundwater samples from monitoring wells in the Anderson and Canyon coal beds versus (A) $\mathrm{SO}_{4}{ }^{2-},(\mathrm{B})$ alkalinity, (C) $\mathrm{NH}_{4}{ }^{+}$, and (D) dissolved organic carbon (DOC) concentrations. Nearby coal-bed methane (CBM) production wells reported in Bates et al. (2011) are shown for comparison at the top of the graphs, as CBM production wells contained detectable $\mathrm{CH}_{4}$ (measured as mole \%, rather than dissolved $\mathrm{CH}_{4}$ concentration). Thus, for comparison purposes the CBM production well data is at the top of the graph so that the range of other values in the CBM production wells could be compared to the groundwater monitoring well data.

Figure 3. Carbon and sulfur isotope indicators of microbial processes. A) $\delta^{13} \mathrm{C}$ value of dissolved inorganic carbon (DIC) versus alkalinity. B) $\delta^{34} \mathrm{~S}$ value of $\mathrm{SO}_{4}{ }^{2-}$ versus $\mathrm{SO}_{4}{ }^{2-}$ concentration. The symbols are the same as in Figure 2. CBM production well data are from Bates et al. (2011).

Figure 4. Dissolved and produced gas isotope $\left(\delta^{13} \mathrm{C}-\mathrm{CO}_{2}\right.$ and $\left.\delta^{13} \mathrm{C}-\mathrm{CH}_{4}\right)$ values. Only three of the monitoring wells contained enough dissolved $\mathrm{CH}_{4}$ in groundwater to analyze for $\delta^{13} \mathrm{C}_{-}-\mathrm{CH}_{4}$. Results for nearby coal-bed $\mathrm{CH}_{4}$ production wells are shown for comparison. Dotted lines represent values of $f$, which represents the proportion of coal carbon converted to $\mathrm{CH}_{4}$, assuming $\delta^{13} \mathrm{C}$ of metabolizable coal $\mathrm{C}$ 
is $-25 \%$. Therefore, $f$ records the relative favorability of methanogenesis vs. non-methanogenic pathways, such as sulfate reduction (Vinson et al., 2017).

Figure 5. Principal components analysis of low (green) and high (red) $\mathrm{SO}_{4}{ }^{2-}$ samples from Anderson (घ) and Canyon $(\bullet)$ coal seams based upon the sampled bacterial populations from DMSs. Blue vectors represent aligned bacterial groups, and red vectors represent selected geochemistry.

Figure 6. Principal components analysis of low (green) and high (red) $\mathrm{SO}_{4}{ }^{2-}$ samples from Anderson ( $\square$ ) and Canyon $(\bullet)$ coal seams based upon the sampled archaeal populations from DMSs. Blue vectors represent aligned bacterial groups, and red vectors represent selected geochemistry.

Figure 7. Quantitative PCR for dsrB and mcrA for selected DMS samples listed (left to right) in order of decreasing $\mathrm{SO}_{4}{ }^{2-}$ and increasing $\mathrm{CH}_{4}$ concentrations.

Figure 8. Comparison between high $\mathrm{SO}_{4}{ }^{2-}$ (red) and low $\mathrm{SO}_{4}{ }^{2-}$ (green) bacterial and archaeal community composition shown with a phylogenetic cladogram created using LEfSe analysis. Circles in gold are organisms in the cladagrom that were determined to likely not explain differences between high and low $\mathrm{SO}_{4}{ }^{2-}$ wells based on biological consistency and relevance. Samples were obtained using a DMS, with $\mathrm{SO}_{4}{ }^{2-}$ concentrations determined from water samples prior to deployment of DMS.

Figure S1. Comparison of $0.45 \mu \mathrm{m}$ filtered groundwater samples between high $\mathrm{SO}_{4}{ }^{2-}$ and low $\mathrm{SO}_{4}{ }^{2-}$ (red) bacterial and archaeal community composition shown with a phylogenetic cladogram made from LEfSe. Only definitive biomarkers for low $\mathrm{SO}_{4}{ }^{2-}$ wells were identified. 
Figure S2. Relative abundance of detected bacterial populations for the different samples. All of the detected bacterial taxa are represented at the order level. The larger cicles are representative of an overall higher percentage of the relative abundance according to the given scale.

Figure S3. Relative abundance of detected archaeal populations for the different samples. All of the detected archaeal taxa are represented at the order level. The larger cicles are representative of an overall higher percentage of the relative abundance according to the given scale.

Table 1. Coal bed monitoring well sample locations, depth, field parameters, major ion chemistry, and nutrient analyses. Dissolved oxygen (DO) was only measured in 2014. NA is not analyzed.

Table 2. Dissolved methane concentration and dissolved gas (molecular and isotopic) composition of groundwater samples from coal bed monitoring wells. Cells with asterisks indicate methane concentrations were too low for isotopic analysis. ND is not detected, while NA is not analyzed.

Table 3. Field samples for community analyses from both filtered groundwater and diffusive microbial samplers (DMSs) incubated down-well in coal bed monitoring wells. Number of sequences is the number of sequences analyzed for each sample post-filtering. Coverage is the estimated coverage of possible diversity, the observed OTUs (species richness) are empirically determined, and Chao estimates the probable species richness based upon the sampled diversity. Inverse Simpson is a diversity index

Table 4. Stable isotopic composition of water, dissolved inorganic carbon (DIC), and sulfate (asterisks 
indicates sulfate concentrations were too low for isotopic analysis) in groundwater samples from coal bed monitoring wells. 


\begin{tabular}{|c|c|c|c|c|c|c|c|c|c|c|c|c|c|c|c|c|c|c|c|}
\hline Well Nam€ & Latitude & Longitude & $\begin{array}{l}\text { Land } \\
\text { Surface } \\
\text { Elevati } \\
\text { on } \\
\text { (m) }\end{array}$ & $\begin{array}{l}\text { Deptn } \\
\text { Below } \\
\text { Land } \\
\text { Surfa } \\
\text { ce } \\
(\mathrm{m})\end{array}$ & $\begin{array}{l}\text { Date } \\
\text { Sampled }\end{array}$ & $\begin{array}{c}\text { Temp } \\
\left({ }^{\circ} \mathrm{C}\right)\end{array}$ & $\begin{array}{c}\text { DO } \\
\%\end{array}$ & $\mathrm{pH}$ & $\begin{array}{l}\text { Alkalinity } \\
\text { (meq } / \mathrm{kg} \text { ) }\end{array}$ & $\begin{array}{l}\mathrm{Na}^{+} \\
(\mathrm{mM})\end{array}$ & $\begin{array}{c}\mathrm{K}^{+} \\
(\mathrm{mM})\end{array}$ & $\begin{array}{l}\mathrm{Ca}^{2+} \\
(\mathrm{mM})\end{array}$ & $\begin{array}{l}\mathrm{Mg}^{2+} \\
(\mathrm{mM})\end{array}$ & $\begin{array}{c}\mathrm{Cl}^{-} \\
(\mathrm{mM})\end{array}$ & $\begin{array}{l}\mathrm{NO}_{3}^{-} \\
(\mathrm{mM})\end{array}$ & $\begin{array}{l}\mathrm{SO}_{4}{ }^{2-} \\
(\mathrm{mM})\end{array}$ & $\begin{array}{l}\mathrm{DOC} \\
(\mathrm{mM})\end{array}$ & $\begin{array}{l}\mathrm{NH}_{4}^{+} \\
(\mathrm{mM})\end{array}$ & $\begin{array}{l}\mathrm{PO}_{4}^{3-} \\
(\mu \mathrm{M})\end{array}$ \\
\hline HWC & 45.1254 & -106.4836 & 1193 & 71 & $09 / 10 / 2011$ & 13.5 & & 8.5 & 28.97 & 29.33 & 0.13 & 0.11 & 0.09 & 0.52 & $<0.01$ & $<0.01$ & 0.21 & 0.28 & NA \\
\hline HWC & & & & & $30 / 04 / 2014$ & 13.0 & 1.3 & 8.0 & 25.38 & 27.49 & 0.16 & 0.16 & 0.10 & 0.50 & $<0.01$ & 0.00 & 0.39 & 0.08 & 1.41 \\
\hline SH-396 & 45.0490 & -107.0088 & 1205 & 86 & $14 / 08 / 2013$ & 14.6 & & 7.4 & 9.87 & 16.43 & 0.09 & 0.06 & 0.04 & 0.17 & $<0.01$ & 2.60 & 0.12 & 0.03 & 0.43 \\
\hline SH-396 & & & & & $01 / 05 / 2014$ & 13.1 & 2.4 & 7.8 & 13.55 & 16.96 & 0.12 & 0.14 & 0.11 & 0.08 & $<0.01$ & 0.03 & 0.13 & 0.08 & 0.33 \\
\hline CBM02 & 45.1801 & -106.8906 & 1080 & 80 & 09/10/2011 & 13.9 & & 8.5 & 10.64 & 16.16 & 0.12 & 0.19 & 0.10 & 0.12 & $<0.01$ & 2.78 & 0.29 & 0.21 & NA \\
\hline CBM02 & & & & & $30 / 04 / 2014$ & 13.7 & 4.0 & 8.0 & 8.70 & 16.02 & 0.14 & 0.22 & 0.13 & 0.13 & $<0.01$ & 2.91 & 0.15 & 0.04 & 0.63 \\
\hline WR-33 & 45.0067 & -106.9760 & 1141 & 50 & $14 / 08 / 2013$ & 11.7 & & 7.0 & 5.42 & 3.15 & 0.38 & 3.44 & 7.64 & NA & NA & NA & NA & NA & NA \\
\hline WR-33 & & & & & $29 / 04 / 2014$ & 11.7 & 3.6 & 7.0 & 6.02 & 2.92 & 0.35 & 3.17 & 6.74 & 2.16 & 0.17 & 5.09 & 0.37 & $<0.03$ & $<0.03$ \\
\hline WR-34 & 45.0027 & -106.9700 & 1154 & 160 & $01 / 05 / 2014$ & 15.5 & 3.0 & 7.7 & 17.82 & 26.13 & 0.16 & 0.16 & 0.12 & 0.24 & $<0.01$ & 4.38 & 0.79 & 0.07 & 0.80 \\
\hline WR-48 & 44.9939 & -106.9660 & 1130 & 51 & $14 / 08 / 2013$ & 12.3 & & 7.6 & 11.64 & 30.95 & 0.19 & 0.25 & 0.28 & NA & NA & NA & NA & NA & NA \\
\hline WR-48 & & & & & $28 / 04 / 2014$ & 12.3 & 3.9 & 7.7 & 11.05 & 26.64 & 0.18 & 0.22 & 0.23 & 0.23 & $<0.01$ & 7.97 & 0.21 & 0.11 & 0.91 \\
\hline WR-24 & 45.0210 & -106.9885 & 1155 & 45 & 05/10/2011 & 10.7 & & 7.4 & 12.86 & 28.83 & 0.25 & 0.89 & 0.97 & 0.24 & $<0.01$ & 10.35 & 0.16 & 0.46 & $<0.03$ \\
\hline WR-24 & & & & & $29 / 04 / 2014$ & 9.7 & 1.4 & 7.6 & 9.97 & 29.16 & 0.29 & 0.90 & 1.22 & 0.28 & $<0.01$ & 11.50 & 0.17 & 0.19 & $<0.03$ \\
\hline
\end{tabular}

$\mathrm{ND}$, concentration was below detection limit of the instrument

NA was not measured 


\begin{tabular}{|c|c|c|c|c|c|c|c|c|c|c|c|}
\hline \multirow[t]{2}{*}{ Well Name } & \multirow{2}{*}{$\begin{array}{l}\text { Date } \\
\text { Sampled }\end{array}$} & \multirow{2}{*}{$\begin{array}{c}\text { Dissolved } \mathrm{CH}_{4} \\
(\mathrm{mM})\end{array}$} & \multicolumn{6}{|c|}{ Dissolved Gas Composition (mole \%) } & \multicolumn{3}{|c|}{$\delta^{13} \mathrm{C}-\mathrm{CO}_{2} \delta^{13} \mathrm{C}-\mathrm{CH}_{4} \delta^{2} \mathrm{H}-\mathrm{CH}_{4}$} \\
\hline & & & $\mathrm{Ar}$ & $\mathrm{O}_{2}$ & $\mathrm{CO}_{2}$ & $\mathrm{~N}_{2}$ & $\mathrm{CH}_{4}$ & $\mathrm{C}_{2}-\mathrm{C}_{6}$ & $\%$ & $\%$ & $\%$ \\
\hline HWC & \#\#\#\#\#\#\# & NA & 0.083 & 0.460 & 1.310 & 2.560 & 95.540 & 0.038 & 2.2 & -69.4 & -293.0 \\
\hline HWC & \#\#\#\#\#\#\# & 3.74 & 0.097 & 0.770 & 0.860 & 3.740 & 94.490 & 0.038 & 2.0 & -69.1 & -304.3 \\
\hline SH-396 & \#\#\#\#\#\#\# & 0.748 & 0.941 & 1.04 & 3.05 & 52.74 & 42.13 & 0.104 & -19.3 & -85.8 & -328.2 \\
\hline CBM02 & \#\#\#\#\#\#\# & NA & 1.440 & 4.470 & 0.920 & 92.920 & 0.212 & 0.000 & -17.4 & -57.2 & NA \\
\hline CBM02 & \#\#\#\#\#\#\# & 0.00237 & 1.570 & 3.420 & 1.460 & 93.350 & 0.196 & ND & -17.0 & ND & ND \\
\hline WR-33 & \#\#\#\#\#\#\# & 0.0000467 & 1.13 & 6.91 & 8.54 & 83.42 & 0.005 & ND & -20.4 & ND & ND \\
\hline WR-34 & \#\#\#\#\#\#\#\# & 0.00231 & 1.52 & 2.50 & 4.04 & 91.74 & 0.202 & ND & -20.3 & ND & ND \\
\hline WR-48 & \#\#\#\#\#\#\# & 0.00150 & 1.02 & 2.99 & 3.50 & 92.37 & 0.123 & ND & -16.7 & ND & ND \\
\hline WR-24 & \#\#\#\#\#\#\# & NA & 1.330 & 4.810 & 3.910 & 89.830 & 0.101 & 0.000 & -17.8 & NA & NA \\
\hline WR-24 & \#\#\#\#\#\#\# & 0.00112 & 1.380 & 3.290 & 5.100 & 90.140 & 0.088 & ND & -17.7 & ND & ND \\
\hline
\end{tabular}

$\mathrm{ND}$, concentration was below detection limit of the instrument

NA was not measured 


\begin{tabular}{|c|c|c|c|c|c|c|c|c|}
\hline Well Name & Year Sampled & Coal Seam & Sample Type & $\begin{array}{l}\text { Number of } \\
\text { Sequences }\end{array}$ & $\begin{array}{l}\text { Covera } \\
\text { ge }\end{array}$ & $\begin{array}{l}\text { Observed } \\
\text { OTUs }\end{array}$ & Chao & $\begin{array}{l}\text { Inverse } \\
\text { Simpson }\end{array}$ \\
\hline HWC & 2010 & Canyon & Filtered Water & 9295 & 1 & 94 & 94 & 17.4 \\
\hline HWC & 2011 & Canyon & Filtered Water & 14696 & 1 & 95 & 95 & 14.8 \\
\hline HWC & 2011 & Canyon & DMS Samplers & 29838 & 1 & 149 & 149 & 10.9 \\
\hline HWC & 2012 & Canyon & DMS Samplers & 49672 & 1 & 150 & 150 & 8.4 \\
\hline HWC & 2013 & Canyon & DMS Samplers & 69229 & 1 & 126 & 126 & 11.2 \\
\hline HWC & 2013 & Canyon & DMS Samplers & 27188 & 0.99 & 99 & 99 & 8.29 \\
\hline SH-396 & 2015 & Anderson & DMS Samplers & 116254 & 1 & 187 & 187 & 15 \\
\hline CBM02 & 2010 & Canyon & Filtered Water & 33734 & 0.99 & 69 & 69 & 3.83 \\
\hline CBM02 & 2011 & Canyon & Filtered Water & 30797 & 1 & 62 & 62 & 3.54 \\
\hline CBM02 & 2011 & Canyon & DMS Samplers & 181382 & 1 & 124 & 124 & 8.85 \\
\hline CBM02 & 2012 & Canyon & DMS Samplers & 40123 & 0.99 & 103 & 103 & 3.81 \\
\hline CBM02 & 2013 & Canyon & DMS Samplers & 17934 & 0.99 & 73 & 73.1 & 5.86 \\
\hline WR-33 & 2015 & Anderson & DMS Samplers & 134643 & 1 & 145 & 145 & 6.06 \\
\hline WR-34 & 2012 & Anderson & DMS Samplers & 238496 & 0.99 & 123 & 123 & 3.39 \\
\hline WR-48 & 2015 & Anderson & DMS Samplers & 154220 & 1 & 128 & 128 & 4.25 \\
\hline WR-24 & 2010 & Canyon & Filtered Water & 9882 & 0.99 & 59 & 59 & 10.5 \\
\hline WR-24 & 2011 & Canyon & Filtered Water & 18055 & 1 & 91 & 91 & 10.5 \\
\hline WR-24 & 2010 & Canyon & DMS Samplers & 410620 & 1 & 96 & 96 & 1.6 \\
\hline WR-24 & 2012 & Canyon & DMS Samplers & 57963 & 1 & 97 & 97 & 5.37 \\
\hline
\end{tabular}




\begin{tabular}{|c|c|c|c|c|c|c|}
\hline Well Name & $\begin{array}{l}\text { Date } \\
\text { Sampled }\end{array}$ & $\begin{array}{c}\delta^{2} \mathrm{H}-\mathrm{H}_{2} \mathrm{O} \\
\% 0\end{array}$ & $\begin{array}{c}\delta^{18} \mathrm{O}-\mathrm{H}_{2} \mathrm{O} \\
\% 0\end{array}$ & $\begin{array}{c}\delta^{13} \mathrm{C}-\mathrm{DIC} \\
\%\end{array}$ & 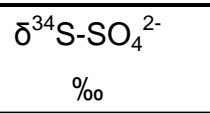 & $\begin{array}{c}\delta^{18} \mathrm{O}-\mathrm{SO}_{4}{ }^{2-} \\
\%\end{array}$ \\
\hline$\overline{H W C}$ & $09 / 10 / 2011$ & -131.5 & $\begin{array}{l}-17.4 \\
\end{array}$ & 12.6 & 2.7 & 15.1 \\
\hline HWC & $30 / 04 / 2014$ & -136.3 & -17.9 & 11.6 & 7.7 & ND \\
\hline SH-396 & $14 / 08 / 2013$ & -163.1 & -21.2 & -8.8 & 22.0 & 5.4 \\
\hline SH-396 & $01 / 05 / 2014$ & -169.4 & -21.7 & -8.4 & ND & ND \\
\hline CBM02 & 09/10/2011 & -164.7 & -20.9 & -7.2 & 20.9 & 11.2 \\
\hline CBM02 & $30 / 04 / 2014$ & -164.6 & -21.4 & -7.5 & 21.1 & -1.4 \\
\hline WR-33 & $29 / 04 / 2014$ & -144.4 & -18.8 & -11.2 & -0.3 & -3.5 \\
\hline WR-34 & $01 / 05 / 2014$ & -164.9 & -21.1 & -10.4 & 19.6 & 1.3 \\
\hline WR-48 & $28 / 04 / 2014$ & -156.0 & -20.1 & -7.8 & 2.3 & -7.5 \\
\hline WR-24 & 05/10/2011 & -163.8 & -21.1 & -7.6 & 6.5 & 2.4 \\
\hline WR-24 & $29 / 04 / 2014$ & -164.4 & -21.2 & -8.3 & 6.5 & 2.7 \\
\hline
\end{tabular}

$\mathrm{ND},\left[\mathrm{SO}_{4}\right]$ too low (insufficient) to measure isotopes 

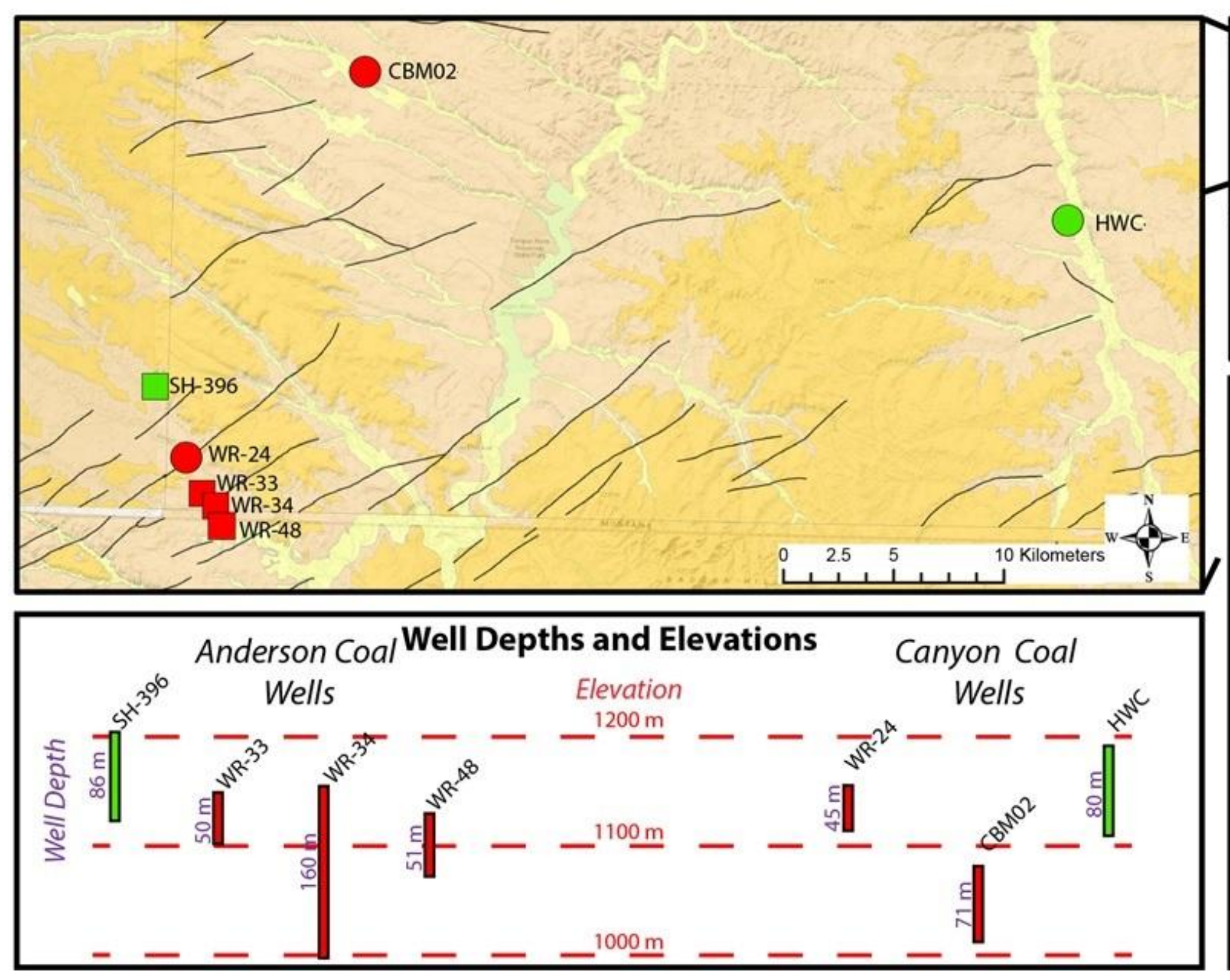

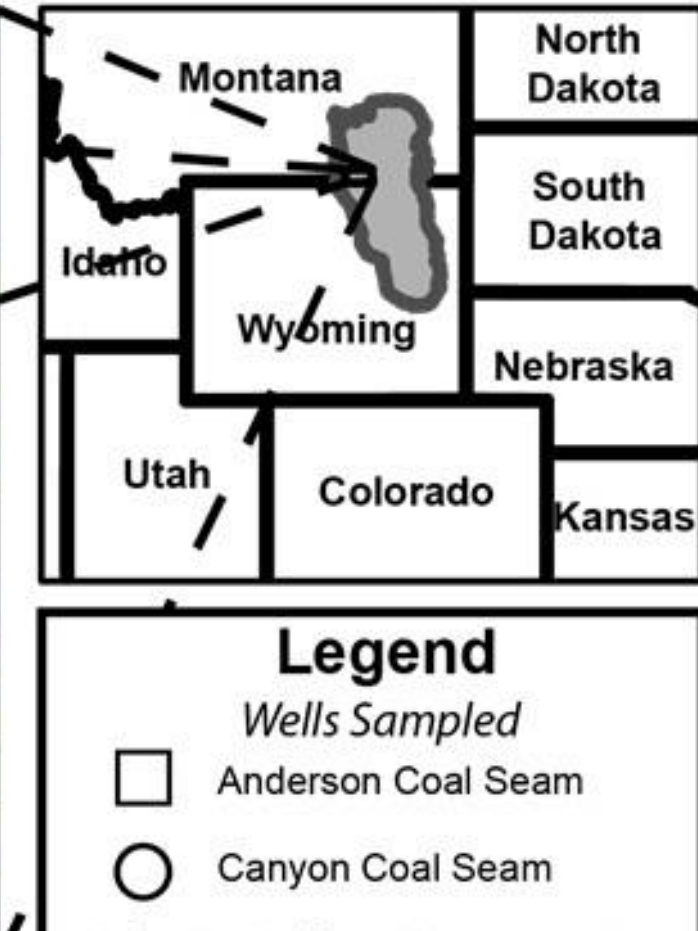

Relative Sulfate Concentration

\begin{tabular}{l} 
Low (<1 mM) \\
High (>1 mM) \\
Surficial Geology \\
Quarternary Alluvium \\
Tongue River Formation \\
Wasatch Formation \\
Faults \\
\hline
\end{tabular}

Figure 1. 

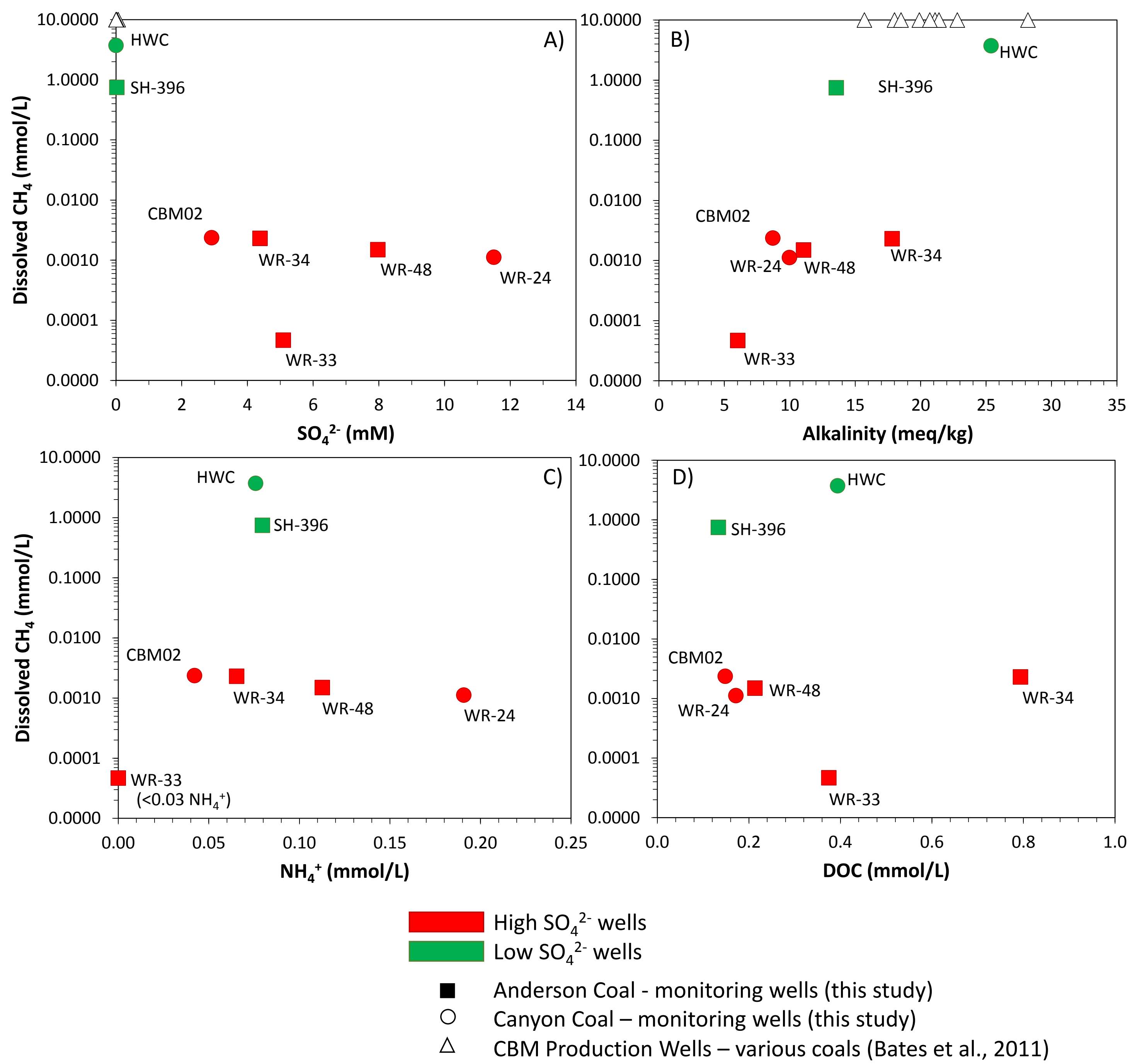

Figure 2. 

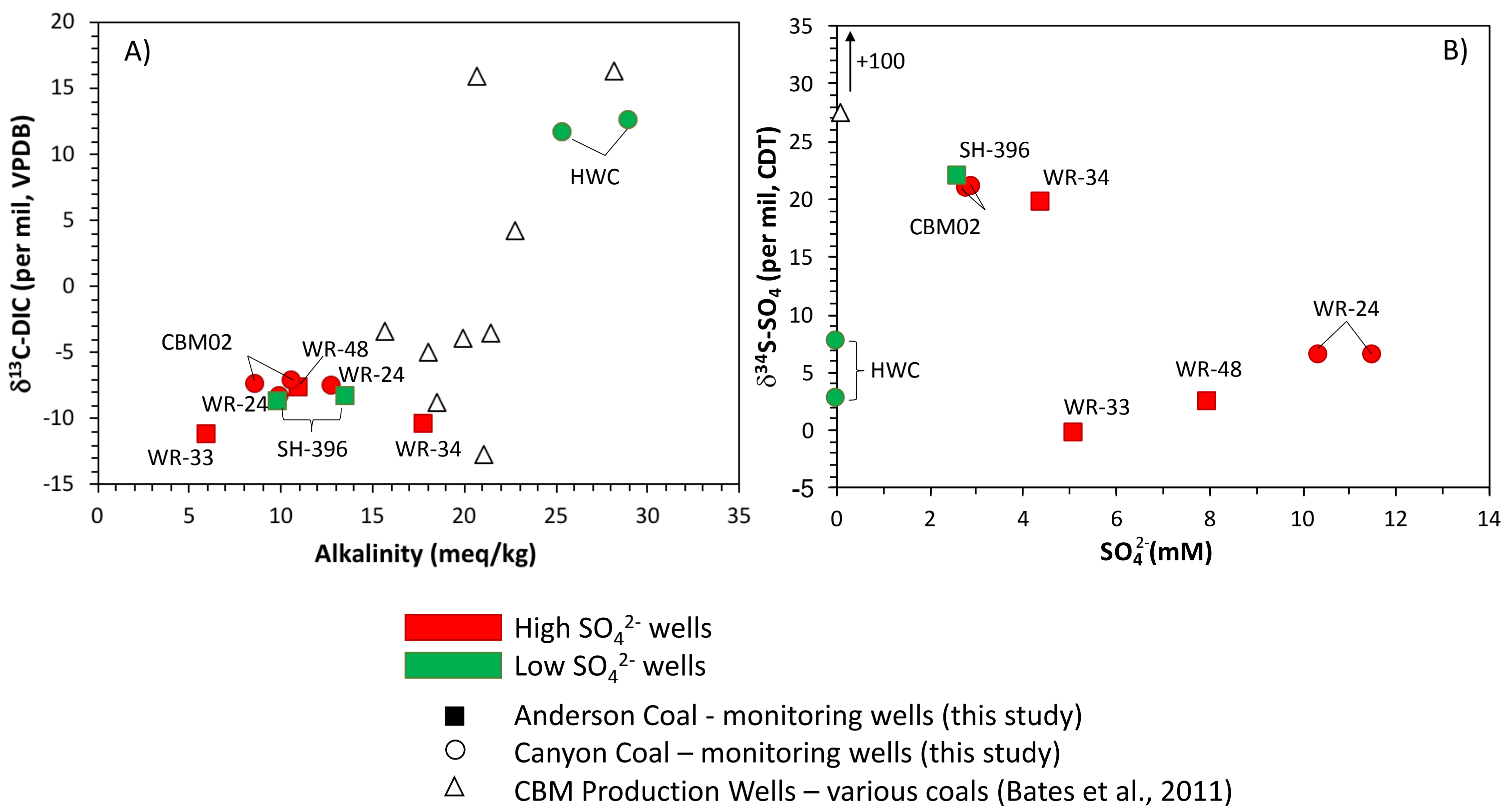

Figure 3. 

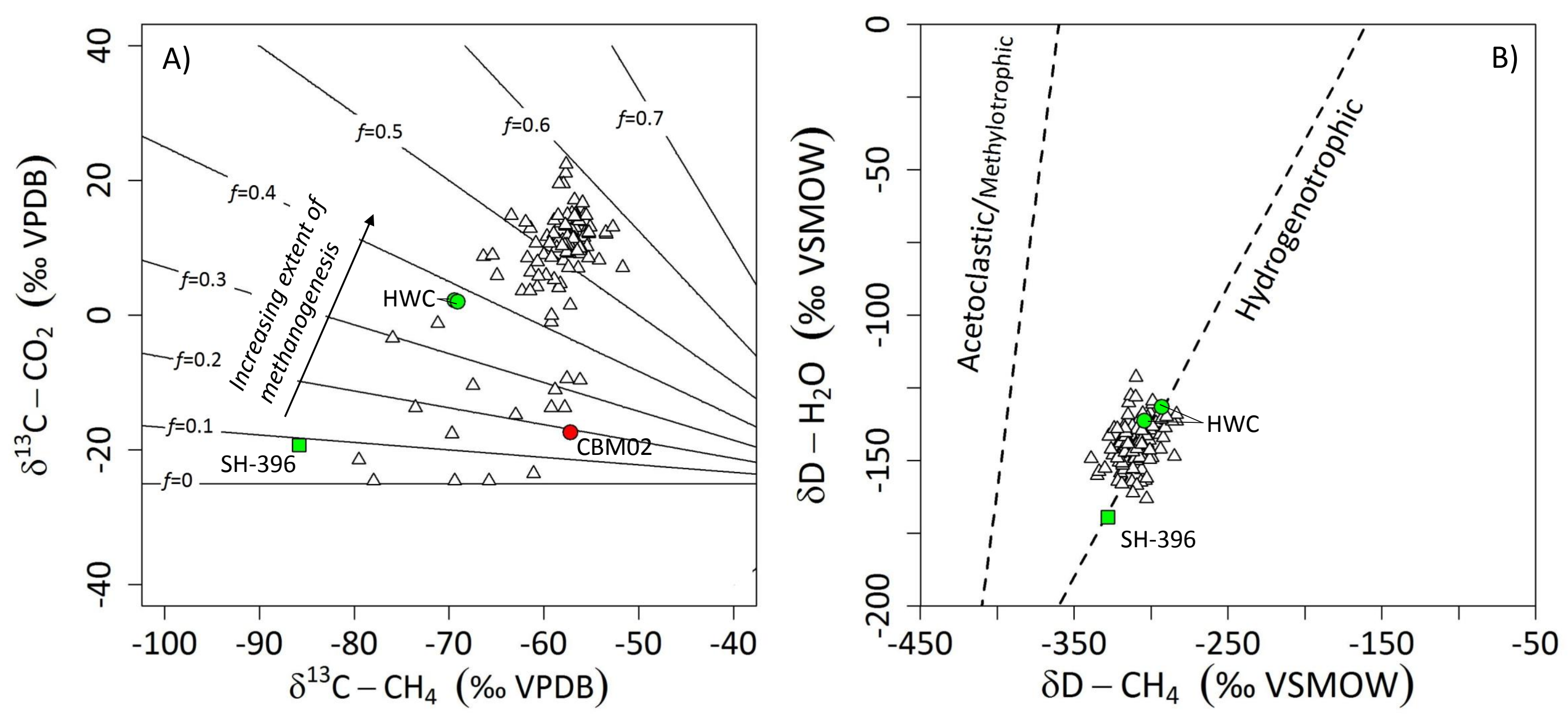

High $\mathrm{SO}_{4}{ }^{2-}$ wells
Low $\mathrm{SO}_{4}{ }^{2-}$ wells

- Anderson Coal - monitoring wells (this study)

$O$ Canyon Coal - monitoring wells (this study)

$\triangle \quad$ CBM Production Wells - various coals (Bates et al., 2011)

Figure 4. 


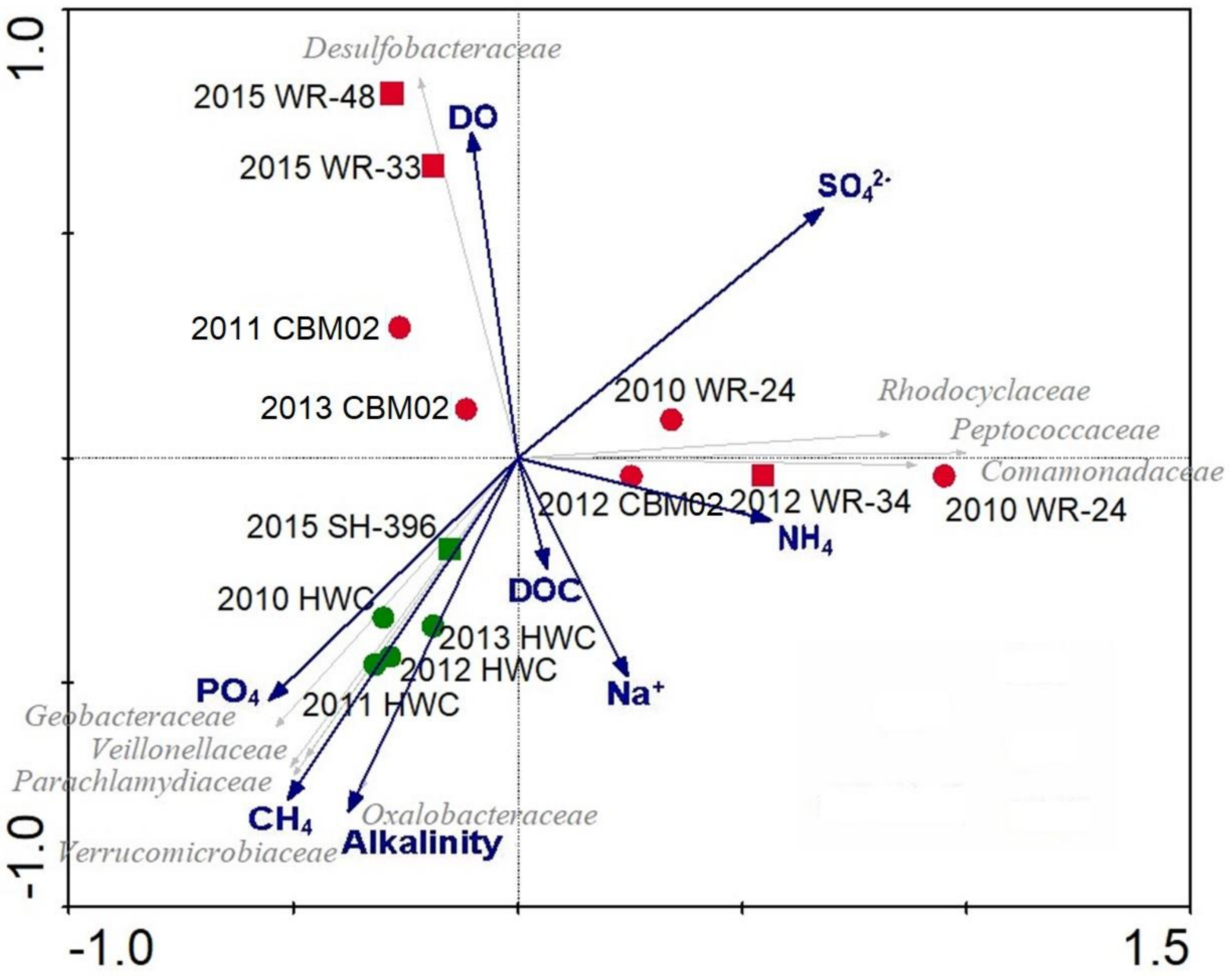

Figure 5. 


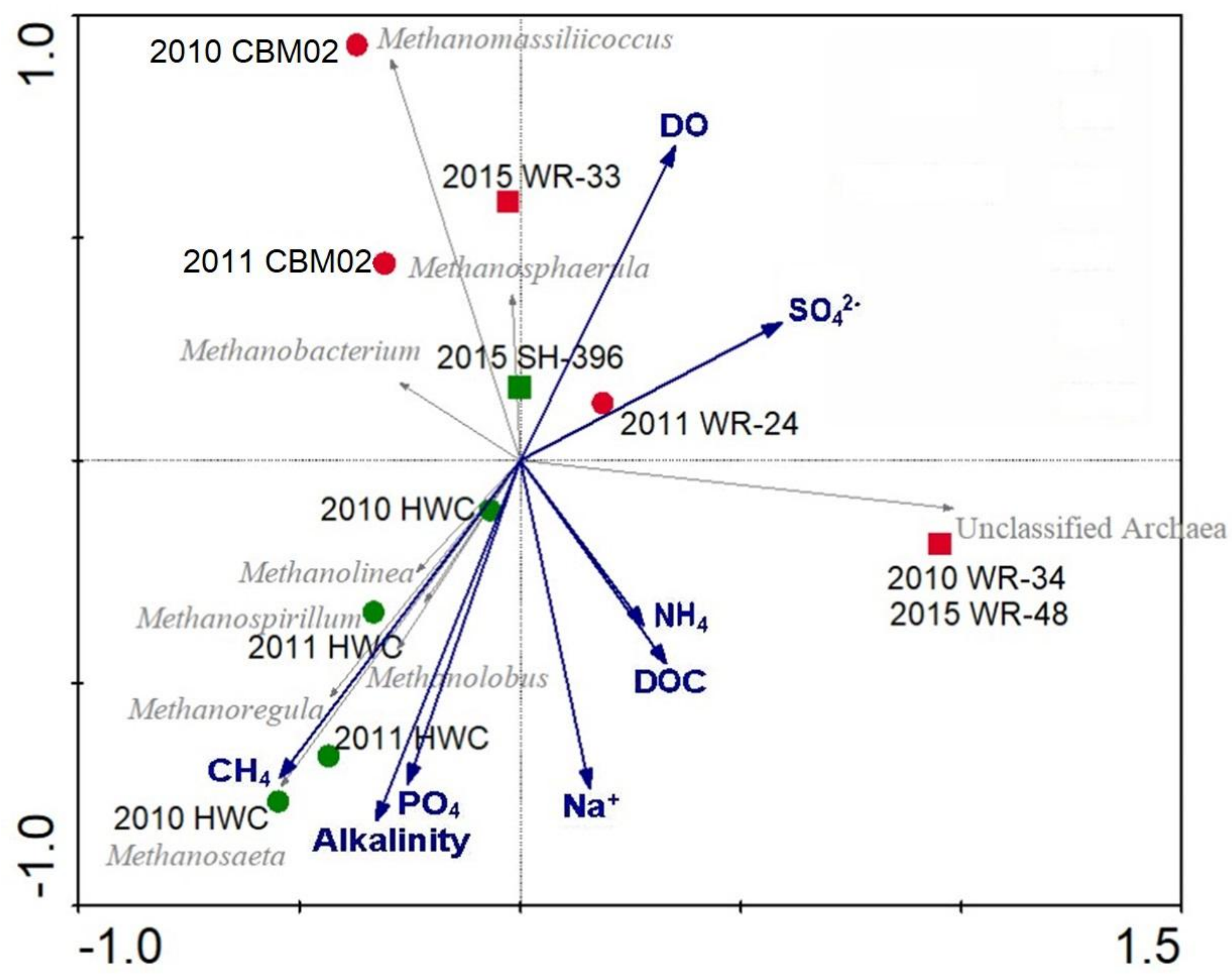

Figure 6. 


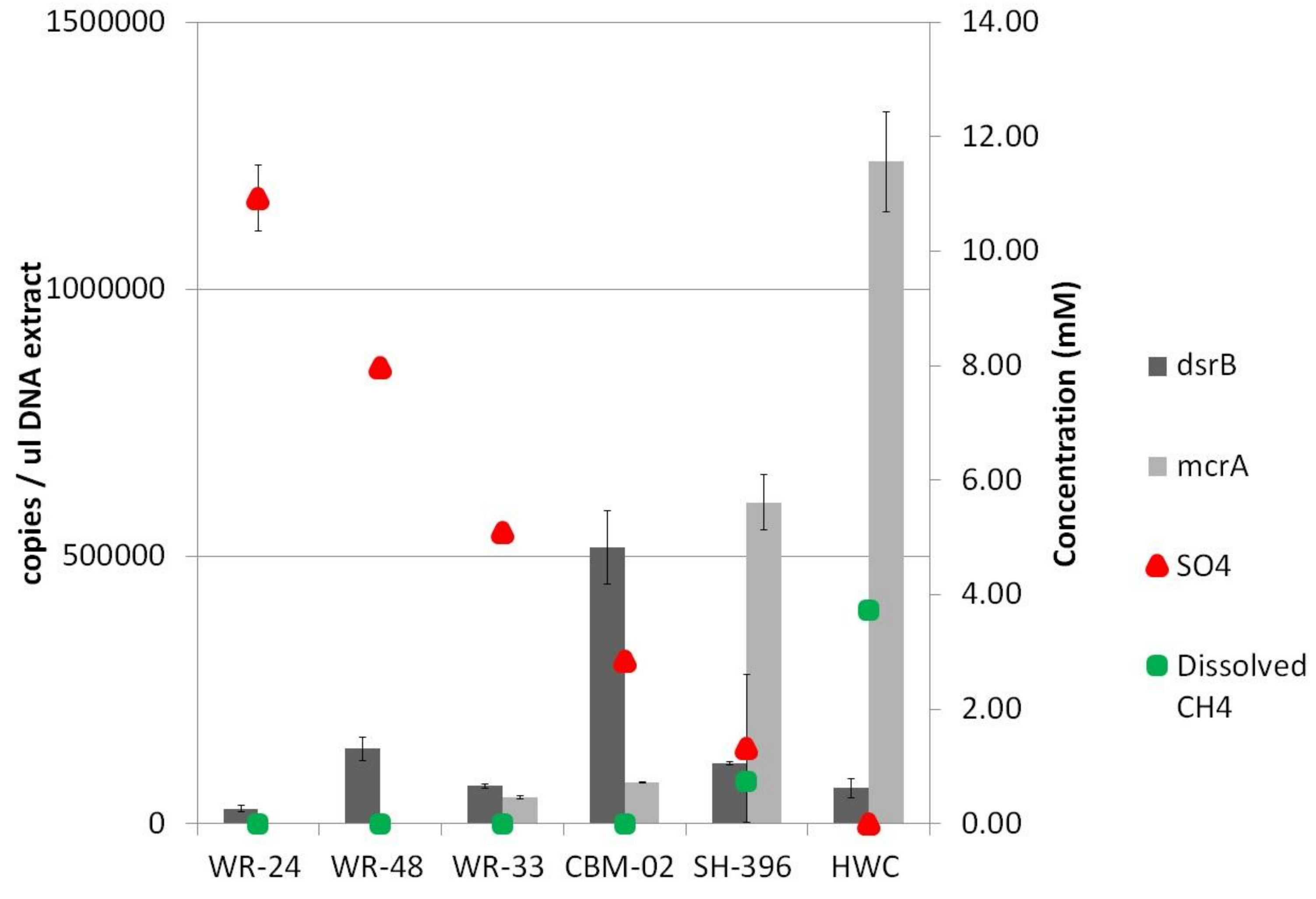

Figure 7. 
High Sulfate

Low Sulfate

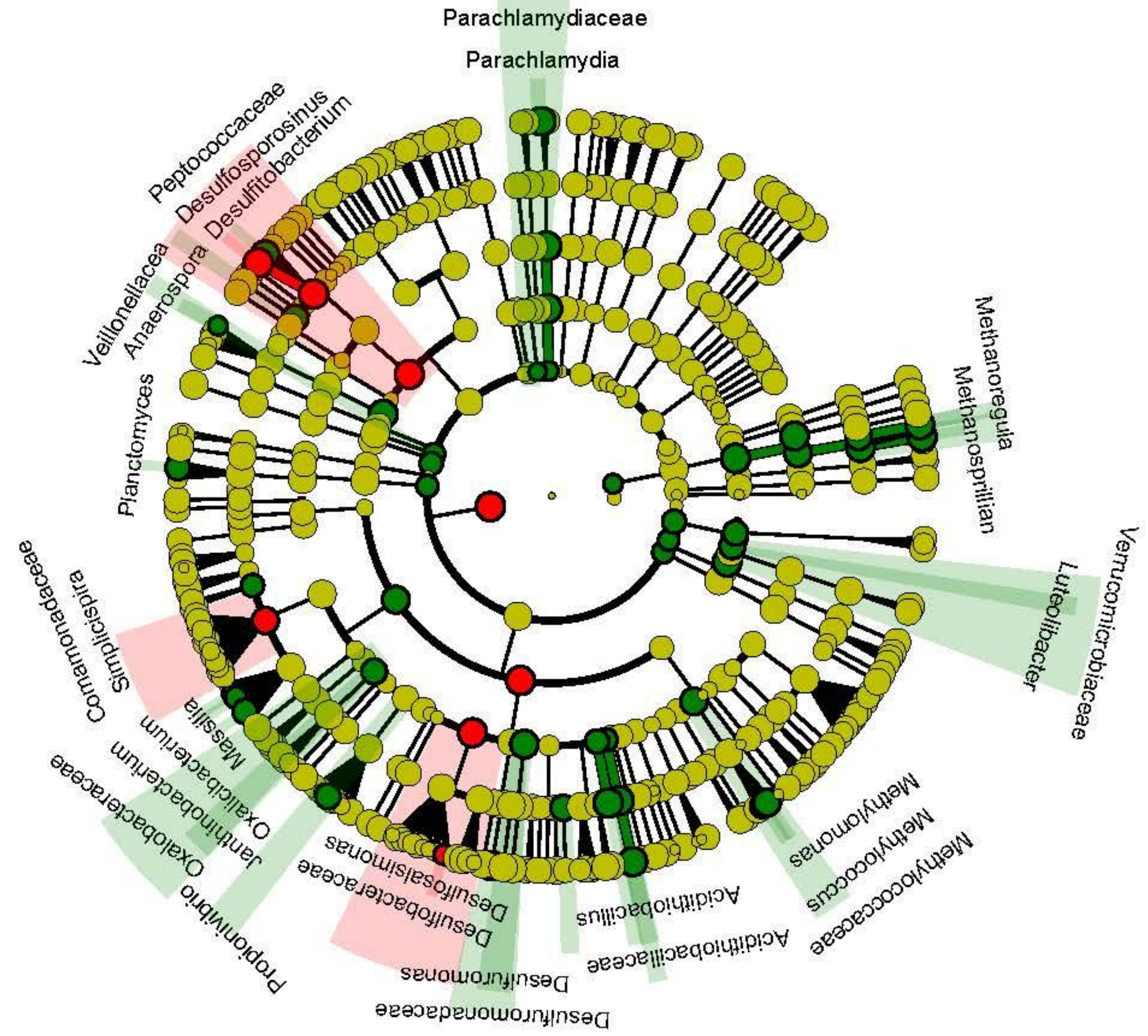

Figure 8. 
Supplemental Figures 


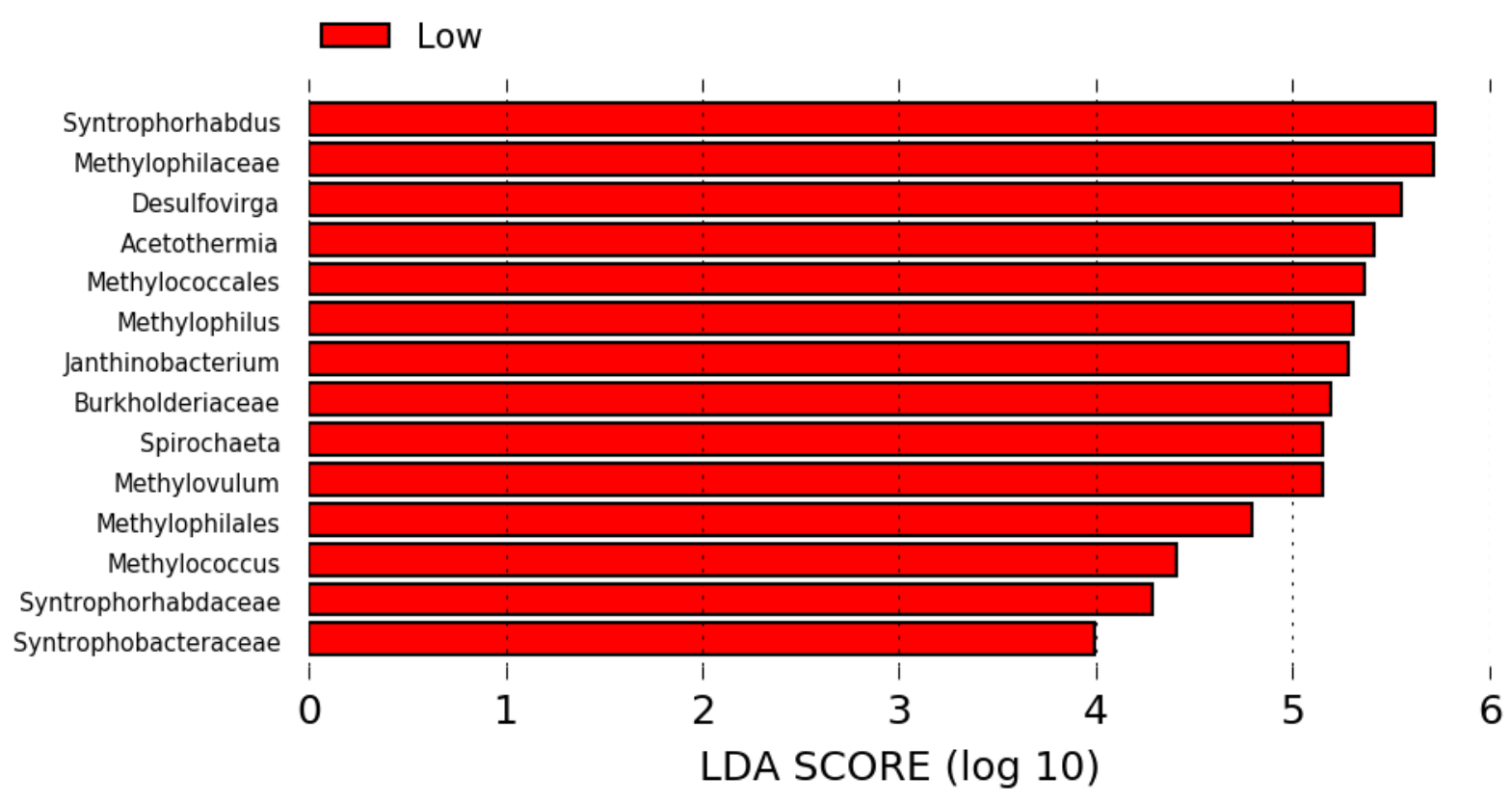

Figure S1. 

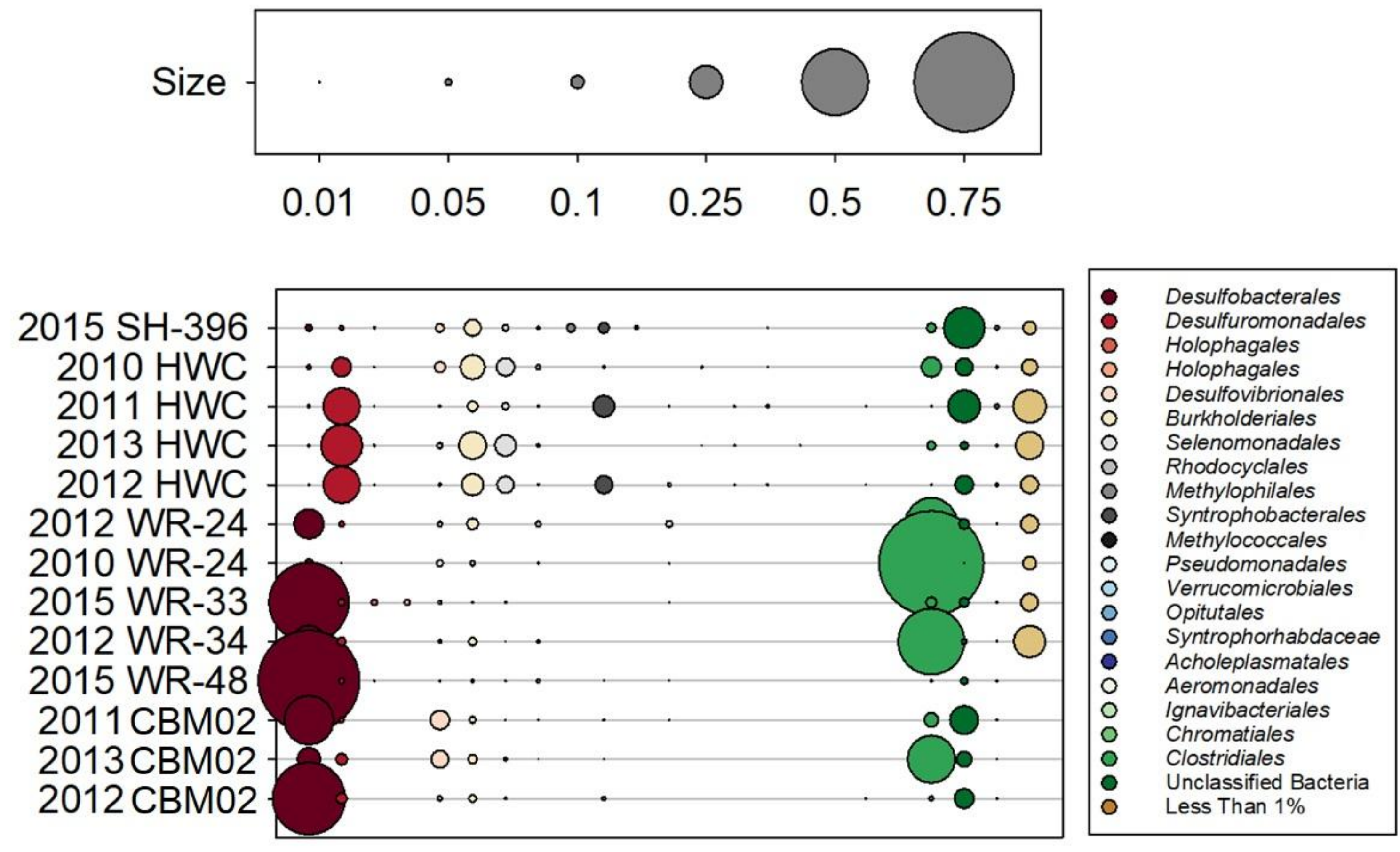

Figure S2. 

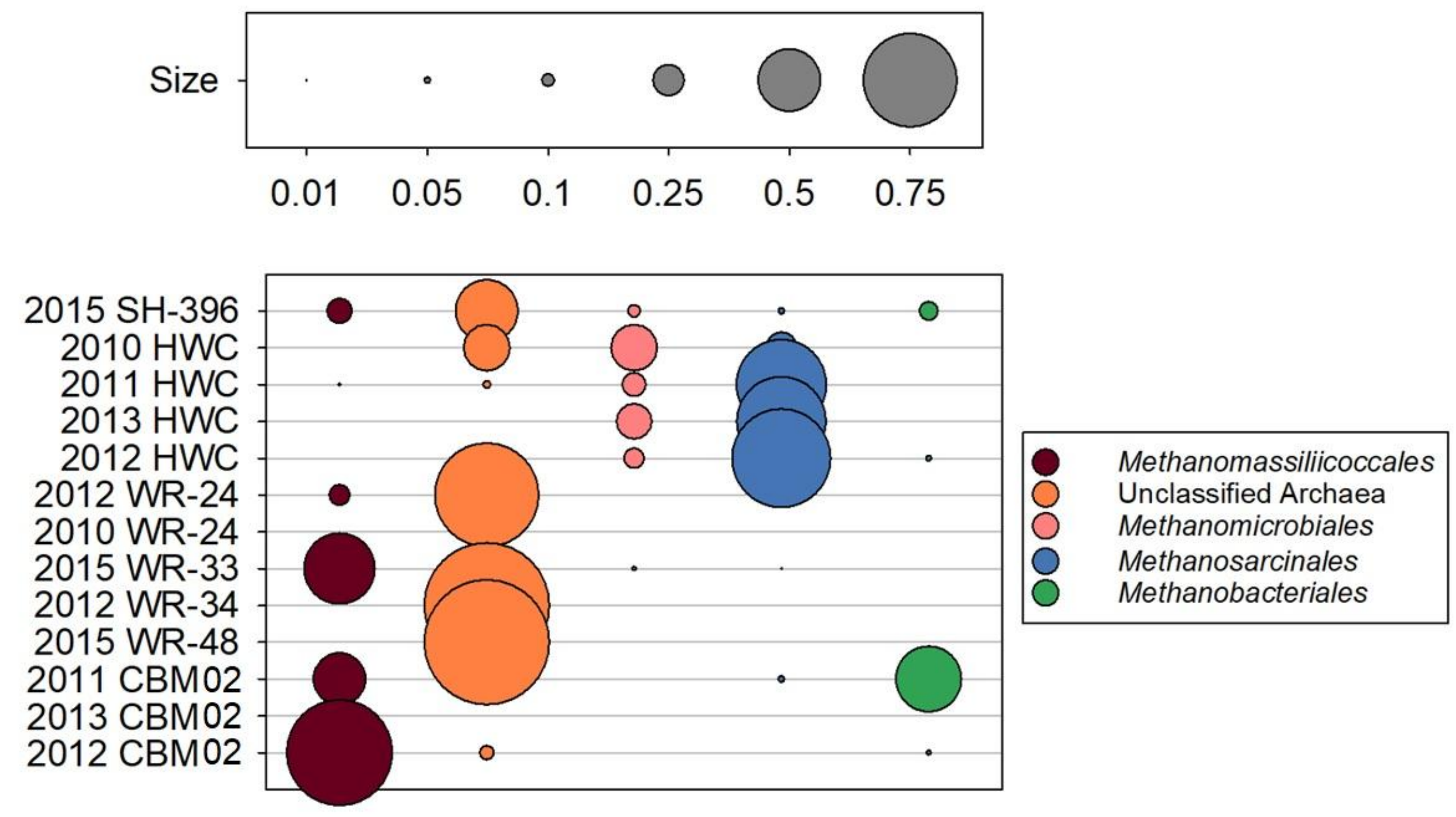

Figure S3. 